
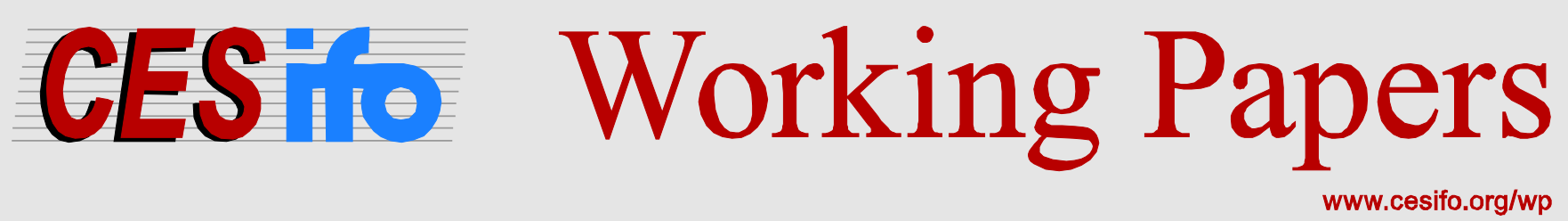

\title{
International R\&D Spillovers and Marginal Social Returns on R\&D
}

\author{
Kazuo Ogawa \\ Elmer Sterken \\ Ichiro Tokutsu
}

\author{
CESIFO WORKING PAPER NO. 6255 \\ CATEgory 6: Fiscal Policy, MaCroeconomics and GROWTH \\ DECEMBER 2016 \\ An electronic version of the paper may be downloaded \\ - from the SSRN website: Www.SSRN.com \\ - from the RePEc website: Www.RePEc.org \\ - from the CESifo website: www.CESifo-group.org/wp
}




\title{
International R\&D Spillovers and Marginal Social Returns on R\&D
}

\begin{abstract}
We analyze the impact of international $R \& D$ spillovers on recipient countries in terms of social and private returns. We divide the aggregate R\&D stock by the business, government and education sectors and examine the impact on Total Factor Productivity. We endogenize the accrual of the $R \& D$ stocks by estimating an $R \& D$ investment function. We find that the marginal social returns on $R \& D$ are much larger than the marginal private returns for $R \& D-$ intensive countries. It implies that $R \& D$ intensive countries are expected to generate more spillovers at the margin, but the observed $R \& D$ stock is smaller than the socially optimal level.
\end{abstract}

JEL-Codes: E220, O320, O330, O470.

Keywords: R\&D, spillovers, total factor productivity, social returns, private returns.

\author{
Kazuo Ogawa* \\ Institute of Social and Economic Research \\ Osaka University \\ 6-1 Mihogaoka, Ibaraki \\ Japan - Osaka, 567-0047 \\ ogawa@iser.osaka-u.ac.jp
}

\author{
Elmer Sterken \\ Institute of Economics, Econometrics and \\ Finance, University of Groningen \\ The Netherlands - 9712 GL Groningen \\ e.sterken@rug.nl
}

\author{
Ichiro Tokutsu \\ Graduate School of Business Administration \\ Konan University \\ Japan - Kobe 658-8501 \\ tokutsu@center.konan-u.ac.jp
}

*corresponding author

The authors are grateful to Francesco Venturini, Ryo Nakajima and participants of the Workshop on R\&D, Technology and Productivity held at the Royal Netherlands Institute in Rome, 2016 spring meeting of the Japanese Economic Association at Nagoya University and the seminar at Hiroshima University for extremely valuable comments and suggestions. This research was financially supported by KAKENHI Grant-in-Aid for Scientific Research (S) \#15H05728, (B) \#25285068 and the program of the Joint Usage/Research Center for "Behavioral Economics” at ISER, Osaka University. 


\section{Introduction}

The Global Financial Crisis of 2008/2009 has had a serious impact on the majority of developed economies. Especially in Europe there is a serious concern for the development of Total Factor Productivity growth. Stiglitz (2012) considers the slowdown and uneven distribution of productivity growth as the important cause of the financial crisis. Van Ark et al. (2013) claim that "TFP has emerged as the Achilles' heel of Europe's growth performance". This typically applies to the 'older' members of the European Union, the EU-15, and maybe less to the accession countries. It is generally believed though that investment in R\&D could stimulate TFP growth, as it is typically the case in the U.S. economy. Investment in R\&D can be transmitted easily with modern ICT, leading to spillovers abroad. On the one hand this could for instance lead to a larger growth potential in the EU (where the innovation space has been enhanced), on the other hand game-theoretic considerations could lead to underinvestment: why should a small open economy invest in R\&D if spillovers of investments abroad could be absorbed? In order to understand the role of R\&D investment in economic development it is highly relevant to analyze the drivers of investment and, more importantly, the impact of own and imported impact of R\&D capital stocks.

$\mathrm{R} \& \mathrm{D}$ investment contributes to economic growth by enhancing productivity. When R\&D spillovers occur internationally, recipient countries also benefit from the fruit of $R \& D$ activities through various channels. For example, when a firm or consumer purchases R\&D-incorporated import products at lower prices than their use values, the welfare of the buyer increases by the difference between prices and use values. When knowledge produced by foreign $R \& D$ activities is available to domestic firms without incurring any costs, possibly due to incomplete patent protection, reverse engineering or imitation, it will also contribute to enhancing productivity of domestic firms. ${ }^{1}$

There is a large body of studies that have examined the impact of international spillovers on recipient countries from a variety of angles. This study is an extensive empirical attempt to investigate the effects of international $R \& D$ spillovers on recipient countries from the viewpoint of $R \& D$ returns. Specifically we estimate the marginal social and private returns on $R \& D$, taking the interplay of $R \& D$ investment behavior among countries into consideration.

Our study is novel in three aspects. First, most of the previous studies have focused

\footnotetext{
${ }^{1}$ Grilliches (1992) calls the former rent spillovers and the latter knowledge spillovers.

${ }^{2}$ See Keller $(2004,2009)$ for detailed survey on international technology spillovers.

3 There are four other channels through which technology is transmitted across countries. One is bilateral export shares. Funk (2001) finds that exporters receive substantial spillovers from
} 
on the impact of the R\&D stock in the business sector on Total Factor Productivity (TFP). We divide the aggregate R\&D stock into the R\&D stocks of the business, government and education sectors and examine the effects of sectoral R\&D stocks on TFP.

Second, we expand the coverage of sample countries to include relatively new EU accession states which the previous studies have not shed light on. These countries are less active in $R \& D$ investment and might benefit more from international $R \& D$ spillovers. Our country set consists of 32 OECD and EU countries during 1995-2009.

Third, we endogenize the accrual of the $R \& D$ stock by estimating the $R \& D$ investment functions. $R \& D$ investment decisions generally depend on the existing own $\mathrm{R} \& \mathrm{D}$ stock as well as foreign $\mathrm{R} \& \mathrm{D}$ stocks. This enables us to compute the social returns on $R \& D$ by incorporating the channel through which a change in the $R \& D$ stock of one country is propagated into the R\&D activities of other countries. To the best of our knowledge, this is the first attempt to estimate marginal social returns on R\&D, taking account of the interplay of $R \& D$ activities across countries.

Let us preview our main findings. We construct a synthetic domestic and foreign R\&D stock composed of business, government and education stocks using a principal component analysis. We find that this synthetic stock exerts significantly positive effects on TFP. The marginal social returns on $R \& D$, based on the coefficient estimates of both the TFP and R\&D investment functions, is much larger than the marginal private returns for $R \& D$-intensive countries. In fact the marginal social return on $R \& D$ of all sectors in R\&D-intensive countries is $251 \%$ on average, which is twice as large as the marginal private returns. On the other hand the marginal social returns of all sectors are lower than the marginal private returns for some of the less R\&D-intensive countries. The marginal social returns of the business sector are larger than the marginal private returns for all sample countries. R\&D-intensive countries have a larger gap between the marginal social and the marginal private returns. It implies that $R \& D$ intensive countries are expected to generate more spillovers at the margin, but the observed $R \& D$ is smaller than the socially optimal level.

The remainder of the paper is organized as follows. In Section 2 we explain special features of this study in association with the related literature. We present a simple model of international R\&D spillovers which serves as a basis to compute social and private returns in Section 3. We describe our dataset and present some descriptive statistics in Section 4. Section 5 shows our estimation results. We present our estimates of marginal social and private returns in Section 6. The last section concludes. 


\section{Features of Our Study and Related Literature}

International technology spillovers are an important item on both the policy and research agenda and have attracted a lot of researchers to investigate this issue mainly from two standpoints. One is the channel through which technology is spread across countries and the other is whether technology spillovers are effective in enhancing economic growth of recipient countries. Coe and Helpman (1995) (henceforth $\mathrm{CH}$ ) estimate the magnitude of international technology spillovers through import flows, using panel data of 22 countries. The $\mathrm{CH}$ study finds that $\mathrm{R} \& \mathrm{D}$ spillovers exert a positive effect on TFP of recipient countries through import flows. The $\mathrm{CH}$ study gave an impetus to the research on technology spillovers across border and their impact. $^{2}$ Our study follows this stream and is also an empirical investigation into the effects of international technology spillover on economic activities of recipient countries. This section briefly reviews the literature of international technology spillovers and explains the contribution of our study to the literature.

Much attention has been paid to the channels through which technology is spread across countries. This issue boils down to the empirical methodology to construct the foreign $R \& D$ stock. In general the foreign $R \& D$ stock is expressed as a weighted sum of domestic R\&D stocks and its weights reflect the transmission mechanism of technology. Several channels have been proposed to describe the propagation of technology across borders. ${ }^{3}$ The $\mathrm{CH}$ study uses bilateral import shares as weights on the premise that imports embody the technological knowledge of trade partners. Lichtenberg and Van Pottelsberghe de la Potterie (1998) (henceforth LP) suggest an alternative weighting

\footnotetext{
2 See Keller $(2004,2009)$ for detailed survey on international technology spillovers.

3 There are four other channels through which technology is transmitted across countries. One is bilateral export shares. Funk (2001) finds that exporters receive substantial spillovers from their customers. His evidence is consistent with the learning-by-exporting literature that firms improve their performance after entering export markets. Second, foreign direct investment (FDI) has been used as a vehicle to transfer international technology. Firm-specific technology is transferred across countries by sharing technology among multinational parents and affiliates. The studies relating technology spillovers to FDI activities are Aitken and Harrison (1999), Globermann et al. (2000), Xu (2000), Branstetter (2001), Van Pottelsberghe de la Potterie and Lichtemberg (2001), Javorcik (2004), Haskel, Pereira and Slaughter (2002), Blalock and Gertler (2008), Javorcik and Spataream (2008), Keller (2009) and Keller and Yeaple (2009) among others. Third, Keller (2002) uses the bilateral geographical distance between countries to measure the magnitude of productivity gains from $R \& D$ spending of two countries. Fourth, bilateral technological proximity between countries á la Jaffe (1986) has been used as weights attached on domestic R\&D stock. Patent citations are one of the popular indicators to measure the proximity of the countries in technology space. The studies along this line are Park (1995), Sjöholm (1996), Verspagen (1997), Eaton and Kortum (1999) and Guellec and van Pottelsberghe de la Potterie (2004) among others.
} 
scheme free of aggregation and indexation biases in $\mathrm{CH}$. Keller (1998) has demonstrated that the import shares in the construction of the foreign R\&D stock are not essential to obtain the $\mathrm{CH}$ results. Furthermore, Keller (1998) uses randomly created import shares to create the counterfactual foreign R\&D stock, which performed as well as the $\mathrm{CH}$ measure in terms of explanatory power. Coe and Hoffmaister (1999) showed that Keller's weights are essentially simple averages with a random error. Xu and Wang (1999) make use of capital goods trade as conduit for R\&D spillovers. Import share is used by quite a few studies such as Lumenga-Neso et al. (2005), Lee (2006), Madsen (2007), Zhu and Jeon (2007), Acharya and Keller (2009) and Coe et al. (2008).

We also use bilateral import shares to create the foreign R\&D stock. Specifically we compare three measures of the import share: a simple average, the $\mathrm{CH}$ weight and the LP weight. Detailed explanations to construct three measures of R\&D stock will be given in Section 4. We demonstrate that the foreign R\&D stock based on LP weights contains richer information than any other measure.

Our contribution to the literature of international technology spillovers is threefold. First, we enlarge the coverage of the sample countries to include relatively new EU accession states. ${ }^{4}$ Most of the past studies have covered only OECD countries or industrialized countries. ${ }^{5}$ Industrialized countries are active in R\&D investment and potential suppliers of technology. Therefore there is a large body of studies about technology spillovers across these countries. However, the previous studies have not shed light on the extent to which relatively new EU accession states benefit from international $R \& D$ spillovers. It is one of our purposes to explore the technology spillovers to emerging EU countries.

The second contribution is to divide total $R \& D$ stock into sectoral $R \& D$ stocks and examine the impact of sectoral R\&D spillovers on TFP. Most of the past studies have investigated the impact of $\mathrm{R} \& \mathrm{D}$ spillovers in the business sector on productivity. We divide the total R\&D stocks into three sectors: the business, government and education sectors and estimate the contribution of $R \& D$ spillovers in each sector to productivity. In industrialized countries the $R \& D$ stock in the business sector accounts for a relatively large share of total R\&D stocks. For example, the share of R\&D stock in the business sector in 2009 exceeds $70 \%$ for Finland, Japan, Luxembourg, Sweden and the US. However, the share of R\&D stock in the government sector is large for relatively new

\footnotetext{
${ }^{4}$ Relatively new EU accession states in our sample are Cyprus, Hungary, Malta, Bulgaria, Czech Republic, Estonia, Latvia, Lithuania, Poland, Romania, Slovak Republic and Slovenia.

${ }^{5}$ Coe et al. (1997) and Seck (2012) are exceptions. They explore the extent to which developing countries benefit from technology spillovers from advanced countries (North-South $\mathrm{R} \& \mathrm{D}$ spillovers).
} 
EU accession states. It is larger than $20 \%$ in 2009 except for Malta and Estonia. The $\mathrm{R} \& \mathrm{D}$ stock in the education sector is also non-negligible. The share of the R\&D stock in the education sector in 2009 exceeds $20 \%$ for two-third of the sample countries. Government and education R\&D stocks have a direct impact on the creation of scientific and basic knowledge. In spite of the importance of government and education $R \& D$ activities, there have been very few studies to tackle the effects of public $R \& D$ stock on productivity. ${ }^{6}$

The third contribution, which is the bottom line of our study, is to estimate marginal social returns on $\mathrm{R} \& \mathrm{D}$, taking international spillovers into consideration. To the best of our knowledge, this is the first attempt to estimate marginal social returns on R\&D, taking account of the interplay of $R \& D$ activities across countries. $R \& D$ investment decisions generally depend on the existing own R\&D stock as well as foreign R\&D stocks. Therefore, an exogenous shock to $R \& D$ stock in one country is propagated into the $R \& D$ stocks of other countries by way of the interplay of $R \& D$ investment across countries, which eventually affects the total output of all countries. We compute the marginal social returns on $R \& D$ as well as marginal private returns for each country by estimating this propagation process. Specifically we follow the procedure taken by Bloom et al. (2013), who develop a methodology for computing the social and private returns to $R \& D$, measured in terms of the output gains generated by a marginal increase in R\&D over heterogenous firms.

\section{Theoretical Structure of International R\&D Spillovers}

This section describes the mechanism of international R\&D spillovers. Our model is simple and consists of two equations: a production function and an R\&D investment function, both of which depend on domestic and foreign R\&D stocks. ${ }^{7}$

We assume that there are $\mathrm{N}$ countries across which technology is spread by way of $\mathrm{R} \& \mathrm{D}$ stocks. The production function is a Cobb-Douglas type where the gross output is produced by labor, intermediate inputs, the capital stock, the domestic R\&D stock and the foreign R\&D stock. The production function is expressed as

\footnotetext{
${ }^{6}$ The studies examining the relationship between public R\&D activities and productivity are Adams (1990), Nadiri and Mamuneas (1994), Park (1995) and Guellec and Van Pottelsberghe de la Potterie (2004).

7 The following model is basically borrowed from Bloom et al. (2013). This model is extended in Appendix $\mathrm{C}$ so that the R\&D stock may be divided into three sectoral R\&D stocks.
} 


$$
\begin{gathered}
\ln X_{i}=\varphi_{0}+\varphi_{K} \ln K_{i}+\varphi_{L} \ln L_{i}+\varphi_{I M} \ln I M_{i}+\varphi_{1} \ln S_{i}^{d}+\varphi_{2} \ln S_{i}^{f}, \\
(i=1, \cdots, N),
\end{gathered}
$$

where $X_{i}$ : gross output of country $i$,

$K_{i}$ : capital stock of country $i$ at the beginning of period,

$L_{i}$ : labor input of country $i$,

$I M_{i}$ : intermediate input of country $i$,

$S_{i}^{d}$ : domestic R\&D stock of country $i$ at the beginning of period,

$S_{i}^{f}$ : foreign R\&D stock of country $i$ at the beginning of period and

$N$ : number of countries

The foreign $R \& D$ stock is a linear combination of each country's domestic R\&D stock or

$$
\ln S_{i}^{f}=\ln \left(\sum_{j \neq i} \alpha_{i j} S_{j}^{d}\right)
$$

As is shown in the Appendix A, the logarithm of the foreign $R \& D$ stock is approximately written as a linear combination of each country's logarithmic domestic R\&D stock. In other words,

$$
\ln \left(\sum_{j \neq i} \alpha_{i j} S_{j}^{d}\right)=\lambda_{i}+\sum_{j \neq i} \theta_{i j} \ln S_{j}^{d} .
$$

Substituting eq. (2) into eq. (1), we obtain

$$
\begin{aligned}
\ln X_{i}=\left(\varphi_{0}\right. & \left.+\varphi_{2} \lambda_{i}\right)+\varphi_{K} \ln K_{i}+\varphi_{L} \ln L_{i}+\varphi_{I M} \ln I M_{i}+\varphi_{1} \ln S_{i}^{d} \\
& +\varphi_{2} \sum_{j \neq i} \theta_{i j} \ln S_{j}^{d} .
\end{aligned}
$$

In matrix notation, eq. (3) is written as

$$
\ln \mathbf{x}=\boldsymbol{\varphi}_{\mathbf{0}}+\boldsymbol{\varphi}_{K} \ln \mathbf{k}+\boldsymbol{\varphi}_{L} \ln \mathbf{1}+\boldsymbol{\varphi}_{I M} \ln \mathbf{i m}+\boldsymbol{\Phi} \ln \mathbf{s}^{d},
$$

where

$$
\ln \mathbf{x}=\left[\begin{array}{c}
\ln X_{1} \\
\ln X_{2} \\
\vdots \\
\ln X_{N}
\end{array}\right], \ln \mathbf{k}=\left[\begin{array}{c}
\ln K_{1} \\
\ln K_{2} \\
\vdots \\
\ln K_{N}
\end{array}\right], \ln \mathbf{l}=\left[\begin{array}{c}
\ln L_{1} \\
\ln L_{2} \\
\vdots \\
\ln L_{N}
\end{array}\right], \ln \mathbf{i m}=\left[\begin{array}{c}
\ln I M_{1} \\
\ln I M_{2} \\
\vdots \\
\ln I M_{N}
\end{array}\right], \ln \mathbf{s}^{d}=\left[\begin{array}{c}
\ln S_{1}^{d} \\
\ln S_{2}^{d} \\
\vdots \\
\ln S_{N}^{d}
\end{array}\right],
$$




$$
\boldsymbol{\varphi}_{\mathbf{0}}=\left[\begin{array}{c}
\varphi_{0}+\varphi_{2} \lambda_{1} \\
\varphi_{0}+\varphi_{2} \lambda_{2} \\
\vdots \\
\varphi_{0}+\varphi_{2} \lambda_{N}
\end{array}\right], \boldsymbol{\Phi}=\left[\begin{array}{cccc}
\varphi_{1} & \varphi_{2} \theta_{12} & \cdots & \varphi_{2} \theta_{1 N} \\
\varphi_{2} \theta_{21} & \varphi_{1} & \cdots & \varphi_{2} \theta_{2 N} \\
\vdots & \vdots & \ddots & \vdots \\
\varphi_{2} \theta_{N 1} & \varphi_{2} \theta_{N 2} & \cdots & \varphi_{1}
\end{array}\right]
$$

$R \& D$ investment function is specified as a function of domestic and foreign $R \& D$ stocks, output growth rate, and debt outstanding or

$$
\ln R_{i}=\mu_{0}+\mu_{1} \ln S_{i}^{d}+\mu_{2} \ln S_{i}^{f}+\mu_{3} \Delta \ln X_{i}+\mu_{4} \ln D_{i},(i=1,2, \cdots, N),
$$

where $R_{i}: \mathrm{R} \& \mathrm{D}$ investment in the business sector of country $i$ and

$D_{i}$ : Debt outstanding in the business sector of country $i$.

Substituting eq. (2) into eq. (5), we have

$$
\begin{aligned}
& \ln R_{i}=\left(\mu_{0}+\mu_{2} \lambda_{i}\right)+\mu_{3} \Delta \ln X_{i}+\mu_{4} \ln D_{i} \\
& +\left(\mu_{1} \ln S_{i}^{d}+\mu_{2} \sum_{j \neq i} \theta_{i j} \ln S_{i}^{d}\right) .
\end{aligned}
$$

Now we evaluate eq. (6) in the steady state. In the steady state, the R\&D stock is proportional to R\&D investment or

$$
S_{i}^{d}=\frac{R_{i}}{\delta}
$$

Moreover, the growth rate of $X_{i}$ is constant, say $g_{i}$ in steady state or

$$
\Delta \ln X_{i}=g_{i}
$$

Substituting eq. (8) and the logarithm of eq. (7) into eq. (6),

$$
\begin{aligned}
\ln S_{i}^{d}= & \left(\mu_{0}+\mu_{2} \lambda_{i}-\ln \delta\right)+\mu_{3} g_{i}+\mu_{4} \ln D_{i} \\
& +\left(\mu_{1} \ln S_{i}^{d}+\mu_{2} \sum_{j \neq i} \theta_{i j} \ln S_{i}^{d}\right) .
\end{aligned}
$$

In matrix notation, eq. (9) is written as

$$
\ln \mathbf{s}^{d}=\zeta_{0}+\Psi \ln \mathbf{s}^{d}+\mu_{4} \ln \mathbf{d},
$$

where 


$$
\ln \mathbf{d}=\left[\begin{array}{c}
\ln D_{1} \\
\ln D_{2} \\
\vdots \\
\ln D_{N}
\end{array}\right], \boldsymbol{\Psi}=\left[\begin{array}{cccc}
\mu_{1} & \mu_{2} \theta_{12} & \cdots & \mu_{2} \theta_{1 N} \\
\mu_{2} \theta_{21} & \mu_{1} & \cdots & \mu_{2} \theta_{2 N} \\
\vdots & \vdots & \ddots & \vdots \\
\mu_{2} \theta_{N 1} & \mu_{2} \theta_{N 2} & \cdots & \mu_{1}
\end{array}\right], \zeta_{\mathbf{0}}=\left[\begin{array}{c}
\mu_{0}+\mu_{2} \lambda_{1}-\ln \delta+\mu_{3} g_{1} \\
\mu_{0}+\mu_{2} \lambda_{2}-\ln \delta+\mu_{3} g_{2} \\
\vdots \\
\mu_{0}+\mu_{2} \lambda_{N}-\ln \delta+\mu_{3} g_{N}
\end{array}\right]
$$

Total differentiation leads to the conclusion that a one percent change in the R\&D stock of country $i$ induces the changes in each country's R\&D stock as follows:

$$
\mathrm{d} \mathbf{s}^{d}=\mathbf{S}_{d}(\mathbf{I}-\mathbf{\Psi})^{-\mathbf{1}} \mathbf{z}^{*},
$$

where

$$
\mathbf{S}_{d}=\left[\begin{array}{cccc}
S_{1}^{d} & 0 & \cdots & 0 \\
0 & S_{2}^{d} & \cdots & 0 \\
\vdots & \vdots & \ddots & \vdots \\
0 & 0 & \cdots & S_{N}^{d}
\end{array}\right], \mathrm{d} \mathbf{s}^{d}=\left[\begin{array}{c}
\mathrm{d} S_{1}^{d} \\
\mathrm{~d} S_{2}^{d} \\
\vdots \\
\mathrm{d} S_{N}^{d}
\end{array}\right] \text { and }
$$

$\mathbf{z}^{*}$ : an $N \times 1$ vector with one in the $i$-th position and zero elsewhere.

We can also compute the changes in each country's gross output induced by the changes in R\&D stocks, using the production function eq. (4), as

$$
\mathrm{d} \mathbf{x}=\mathbf{D}_{X} \boldsymbol{\Phi}(\mathbf{I}-\Psi)^{-1} \mathbf{z}^{*}
$$

where

$$
\mathbf{D}_{X}=\left[\begin{array}{cccc}
X_{1} & 0 & \cdots & 0 \\
0 & X_{2} & \cdots & 0 \\
\vdots & \vdots & \ddots & \vdots \\
0 & 0 & \cdots & X_{N}
\end{array}\right], \mathrm{d} \mathbf{x}=\left[\begin{array}{c}
\mathrm{d} X_{1} \\
\mathrm{~d} X_{2} \\
\vdots \\
\mathrm{d} X_{N}
\end{array}\right]
$$

Now we define the marginal social returns (MSR) on R\&D of country $i$ as the increase in gross output of all the countries generated by a marginal increase in R\&D stock of country $i$, taking the induced changes in R\&D stocks of other countries into consideration.

Specifically it is written as

$$
M S R_{i}=\frac{(\mathrm{d} \mathbf{x})^{\prime} \mathbf{z}}{\left(\mathrm{d} \mathbf{s}^{d}\right)^{\prime} \mathbf{z}}
$$


where $\mathbf{z}$ : an $N \times 1$ vector of ones.

Similarly, marginal private returns (MPR) on R\&D of country $i$ is defined as the increase in gross output of country $i$ generated by a marginal increase in its own R\&D stock.

$$
M P R_{i}=\frac{(\mathrm{d} \mathbf{x})^{\prime} \mathbf{z}^{*}}{\left(\mathrm{~d} \mathbf{s}^{d}\right)^{\prime} \mathbf{z}^{*}} .
$$

We can compute both the $M S R_{i}$ and $M P R_{i}$ values from the estimation of the TFPand $R \& D$-investment equations.

\section{Data Description}

The analysis in this paper is based on the data taken from the EuroStat database (EuroStat) and World Input-Output Database (WIOD) of the University of Groningen. Specifically, the former database is used to construct the R\&D capital stock and its sectoral components and the latter is mainly used to construct the data on Total Factor Productivity. The latter also provides the information on the bilateral trade for constructing the foreign R\&D capital stocks.

Due to data availability in the WIOD, the sample period in our study is in principle from 1995 to 2009 and the sample countries are restricted to 32 OECD and 'other' European countries. They are presented in Table A1 in the Appendix. For comparison purpose we show the sample countries in the pioneering work by Coe and Helpman (1995) and Coe et al. (2008).

\subsection{Domestic R\&D Capital Stock}

EuroStat provides the time series of nominal R\&D expenditures in local currency for the business sector, the government sector, the higher-education sector and the non-profit sector as well as the economy as a whole. Nominal R\&D expenditures are converted into real R\&D expenditures by the GDP deflator $(1995=1.00)$ and further converted to 1995 US constant dollars by the exchange rates of the corresponding countries in 1995. GDP deflators and the exchange rates are taken from the Socio Economic Account of the WIOD.

The real R\&D capital stocks (in 1995 US constant dollar) are calculated using the perpetual inventory method. We calculated the real $R \& D$ expenditures and capital stocks by sectors; business, government and education sector as well as for the economy as a whole. In what follows, we will indicate the sectors by superscripts or subscripts; $B$, 
$G$, and $E$ when we need distinction. ${ }^{8}$

The share of each sector both in 1995 and 2009 are presented in Table 1. As can be seen from the table the relative importance of each sector and their inter-temporal transition is quite different by country. For example, the relative shares of the government sector for Eastern Europe countries are high both in 1995 and 2009, while those of the business sector are high for developed countries like Japan, the United States and Western Europe countries. It should be noted that the R\&D capital stock of both government and education sectors occupy non-trivial shares although the previous studies have been mostly based on the R\&D stock of the business sector.

\subsection{Foreign R\&D Capital Stock}

Since the pioneering work by Coe and Helpman (1995), a large number of alternative measures of foreign R\&D capital stock has been proposed, but in this paper we will limit our discussion to the import-related measures. More practically, starting from the simple average of foreign $\mathrm{R} \& \mathrm{D}$ stocks, we will examine the two representative measures developed by Coe and Helpman (1995) and Lichtenberg and Van Pottelsberghe de la Potterie (1998).

The first one is the simple average of the foreign R\&D stock (SA) defined as follows:

$$
S_{i}^{f-S A}=\frac{1}{N-1} \sum_{j \neq i}^{N} S_{j}^{d}
$$

This measure is based on the idea that each country has equal access to a foreign country's R\&D. The domestic R\&D capital stock of a specific country is equally allocated to each foreign country irrespective of the import structure. It should be noted that the SA measure does not take account of the trade structure among countries. In other words, it does not incorporate the information about whether a country is heavily trade-oriented or relatively isolated from the world trade network.

Each country faces the same total sum of domestic R\&D capital stocks over the sample countries for a certain year and consequently a country with a larger domestic R\&D capital stock has a smaller foreign R\&D capital stock. Actually, the correlation coefficient between logarithmic domestic and foreign R\&D capital stocks in 2007 is $-0.59 .^{9}$

\footnotetext{
8 See Appendix B for the detailed procedure to construct the domestic R\&D stock.

${ }^{9}$ We adopt the logarithmic form for the estimation of the TFP function, so we show the correlation in logarithmic terms.
} 
Table 1: Sector shares of the domestic R\&D capital stock: 1995 and 2009

\begin{tabular}{|c|c|c|c|c|c|c|c|c|c|}
\hline & & (1) & $(2)$ & (3) & (4) & (5) & $(6)$ & (7) & (8) \\
\hline & & \multicolumn{4}{|c|}{ Shares in $1995(\%)$} & \multicolumn{4}{|c|}{ Shares in $2009(\%)$} \\
\hline & & Bus. & Gov. & Edu. & Total & Bus. & Gov. & Edu. & Total \\
\hline Australia & AUS & 50.7 & 23.5 & 23.8 & 98.0 & 56.0 & 15.8 & 25.4 & 97.2 \\
\hline Austria & $\mathrm{AUT}^{\mathrm{b})}$ & 63.6 & 6.4 & 29.7 & 99.7 & 68.2 & 5.5 & 25.8 & 99.5 \\
\hline Belgium & BEL & 71.3 & 4.8 & 22.5 & 98.6 & 69.8 & 7.4 & 21.5 & 98.8 \\
\hline Bulgaria & BGR & 49.4 & 42.3 & 8.3 & 100.0 & 28.6 & 61.5 & 9.4 & 99.4 \\
\hline Canada & CAN & 58.1 & 14.4 & 26.8 & 99.3 & 56.8 & 10.3 & 32.4 & 99.5 \\
\hline Cyprus & $\mathrm{CYP}^{\mathrm{b})}$ & 14.1 & 56.1 & 25.0 & 95.2 & 21.7 & 31.8 & 38.5 & 91.9 \\
\hline Czech Republic & CZE & 65.1 & 26.4 & 8.5 & 100.0 & 60.2 & 23.1 & 16.2 & 99.6 \\
\hline Germany & DEU & 66.3 & 15.5 & 18.2 & 100.0 & 69.3 & 14.0 & 16.7 & 100.0 \\
\hline Denmark & DNK & 57.4 & 17.0 & 24.5 & 98.9 & 67.6 & 7.2 & 24.5 & 99.4 \\
\hline Spain & ESP & 48.2 & 18.6 & 32.0 & 98.9 & 54.2 & 17.1 & 28.4 & 99.7 \\
\hline Estonia & $\mathrm{EST}^{\mathrm{b})}$ & 19.7 & 23.8 & 56.0 & 99.5 & 40.9 & 13.0 & 44.0 & 97.9 \\
\hline Finland & FIN & 63.2 & 16.6 & 19.5 & 99.4 & 71.0 & 9.8 & 18.6 & 99.4 \\
\hline France & FRA & 61.0 & 21.0 & 16.7 & 98.7 & 62.6 & 17.3 & 18.8 & 98.7 \\
\hline United Kingdom & GBR & 65.0 & 14.6 & 19.2 & 98.7 & 63.2 & 10.7 & 24.1 & 98.0 \\
\hline Greece & GRC & 29.5 & 25.5 & 44.3 & 99.3 & 28.9 & 20.6 & 45.9 & 95.5 \\
\hline Hungary & HUN & 43.4 & 25.6 & 24.8 & 93.8 & 45.4 & 26.6 & 24.1 & 96.2 \\
\hline Ireland & IRL & 70.1 & 9.0 & 20.4 & 99.5 & 66.9 & 7.3 & 25.8 & 100.0 \\
\hline Italy & ITA & 53.4 & 21.1 & 25.5 & 100.0 & 50.6 & 16.8 & 30.6 & 98.0 \\
\hline Japan & JPN & 65.2 & 9.6 & 20.7 & 95.6 & 75.0 & 8.8 & 13.8 & 97.5 \\
\hline Lithuania & LTU $^{\mathrm{a})}$ & 3.6 & 64.0 & 31.4 & 99.0 & 22.5 & 28.1 & 49.2 & 99.9 \\
\hline Luxembourg & $\operatorname{LUX}^{\mathrm{c})}$ & 92.6 & 7.1 & 0.2 & 100.0 & 86.5 & 11.3 & 2.1 & 100.0 \\
\hline Latvia & LVA & 28.1 & 47.2 & 24.7 & 100.0 & 35.5 & 23.9 & 40.6 & 100.0 \\
\hline Malta & $\mathrm{MLT}^{\mathrm{d})}$ & 24.7 & 16.5 & 58.8 & 100.0 & 58.7 & 5.5 & 35.8 & 100.0 \\
\hline Netherlands & NLD & 52.1 & 18.1 & 28.8 & 99.0 & 52.8 & 13.4 & 33.5 & 99.8 \\
\hline Poland & POL & 38.7 & 35.0 & 26.3 & 100.0 & 32.1 & 36.0 & 31.7 & 99.8 \\
\hline Portugal & PRT & 20.9 & 27.0 & 37.0 & 85.0 & 41.8 & 13.5 & 34.5 & 89.8 \\
\hline Romania & ROU & 77.6 & 19.9 & 2.5 & 100.0 & 52.3 & 31.0 & 16.2 & 99.5 \\
\hline Slovakia & SVK & 53.9 & 40.2 & 5.9 & 100.0 & 51.7 & 31.8 & 16.5 & 99.9 \\
\hline Slovenia & SVN & 46.6 & 25.2 & 27.6 & 99.4 & 59.8 & 23.8 & 16.0 & 99.6 \\
\hline Sweden & SWE & 74.6 & 3.7 & 21.6 & 99.8 & 74.3 & 4.0 & 21.5 & 99.8 \\
\hline Turkey & TUR & 23.6 & 7.4 & 69.0 & 100.0 & 36.6 & 10.4 & 53.0 & 100.0 \\
\hline United States & USA & 70.5 & 14.0 & 12.3 & 96.8 & 70.6 & 12.1 & 13.3 & 96.0 \\
\hline
\end{tabular}

Data source: EuroStat.

Note: For countries with a superscript, the shares are evaluated a) in 1996, b) in 1998, c) in 2000 and d) in 2002 due to the data availability. The shares do not necessarily sum up to $100 \%$ because the non-profit sector is not taken into consideration. 
Taking the trade-related R\&D spillovers into account, Coe and Helpman (1995) propose the foreign $\mathrm{R} \& \mathrm{D}$ capital stocks $(\mathrm{CH})$ weighted by the bilateral import share:

$$
S_{i}^{f-C H}=\sum_{j \neq i}^{N} \frac{M_{i j}}{M_{i}} S_{j}^{d}
$$

where $M_{i j}$ is the nominal import of country $i$ from country $j$ and $M_{i}$ is the total import of country $i$ from $N-1$ trade partners. We take the import data from the world input-output tables of WIOD. Equation (16) indicates that the foreign R\&D capital stock available to country $i$ depends only on the import source shares, but not on the absolute level of import or import intensity. Accordingly the countries with a large import share from countries with a large $R \& D$ capital stock tend to have large foreign $R \& D$ capital stocks even if they have relatively small domestic R\&D capital stocks. As a result, the correlation coefficient between logarithmic domestic and foreign $R \& D$ stock $(\mathrm{CH})$ is moderately positive, 0.58 .

As an alternative measure to $\mathrm{CH}$, taking the 'intensity' of trade into consideration, Lichtenberg and Van Pottelsberghe de la Potterie (1998) propose the following measure (LP) that is often adopted in empirical studies of inter-industry technology:

$$
S_{i}^{f-L P}=\sum_{j \neq i}^{n} \frac{M_{i j}}{Y_{j}} S_{j}^{d}
$$

where $Y_{j}$ is GDP of country $j$. Equation (17) indicates that country $i$ can have access to the fraction of the domestic R\&D stock of country $j$ that depends on the ratio of export from country $j$ to country $i$ to GDP of country $j$.

Suppose that $M_{i j}=M_{j i}$ for countries $i$ and $j$, i.e., bilateral trade is in balance between two countries, but $Y_{i}$ is larger than $Y_{j}$. The LP measure implies that country $i$ receives a larger fraction of domestic $R \& D$ of the trade partner (country $j$ ) than country $j$ does. Countries with large GDP often own a large domestic R\&D stock, so their foreign capital stock measured by LP weight also tends to be large. Actually, the correlation coefficient between the logarithmic domestic and LP measure of foreign $\mathrm{R} \& \mathrm{D}$ capital stock is quite high, 0.93 .

We show the average growth rates of the foreign $R \& D$ stock by these three measures from 1995 to 2009 in Table 2. It should be noted that the average growth rate of domestic R\&D capital stock is $5.43 \%$, while those for the foreign R\&D capital stocks are relatively small except for the LP measure, $1.85 \%$ (SA), $1.65(\mathrm{CH})$ and $5.76(\mathrm{LP})$. It is only the growth rate of the foreign capital stock of the LP measure that is comparable in magnitude to that of domestic R\&D capital stock. 
Table 2: Average growth rates of the foreign R\&D stock (\%): 1995 - 2009

\begin{tabular}{|c|c|c|c|c|c|c|c|c|c|c|c|c|}
\hline & (1) & (2) & (3) & (4) & (5) & (6) & (7) & (8) & (9) & $(10)$ & $(11)$ & (12) \\
\hline & \multicolumn{4}{|c|}{ Simple average (SA) } & \multicolumn{4}{|c|}{ Coe and Helpman $(\mathrm{CH})$} & \multicolumn{4}{|c|}{$\begin{array}{l}\text { Lichtenberg and } \\
\text { Pottelsberghe (LP) }\end{array}$} \\
\hline & All. & Bus. & Gov. & Edu. & All. & Bus. & Gov. & Edu. & All. & Bus. & Gov. & Edu. \\
\hline AUS & 1.64 & 1.99 & 0.56 & 1.16 & 2.89 & 3.23 & 2.19 & 1.99 & 3.96 & 4.34 & 2.64 & 3.60 \\
\hline $\mathrm{AUT}^{\mathrm{b})}$ & 2.63 & 2.95 & 1.47 & 2.34 & 2.46 & 2.76 & 1.59 & 2.08 & 4.20 & 4.56 & 3.15 & 3.86 \\
\hline BEL & 1.67 & 2.02 & 0.55 & 1.21 & 1.70 & 1.95 & 0.63 & 1.60 & 2.15 & 2.44 & 0.64 & 2.42 \\
\hline BGR & 1.67 & 2.02 & 0.57 & 1.22 & 0.81 & 1.00 & -0.29 & 0.88 & 11.31 & 11.42 & 9.69 & 12.12 \\
\hline CAN & 1.64 & 2.00 & 0.56 & 1.10 & 3.15 & 3.21 & 2.17 & 3.42 & 3.33 & 3.41 & 2.21 & 3.77 \\
\hline $\mathrm{CYP}^{\mathrm{b})}$ & 2.66 & 2.98 & 1.47 & 2.37 & -1.35 & -1.28 & -1.79 & -1.01 & 3.57 & 3.60 & 2.47 & 4.33 \\
\hline CZE & 1.67 & 2.01 & 0.56 & 1.21 & 1.89 & 2.15 & 0.82 & 1.72 & 9.36 & 9.73 & 7.20 & 9.86 \\
\hline DEU & 1.69 & 2.04 & 0.54 & 1.26 & 1.36 & 1.60 & 0.28 & 1.20 & 2.97 & 3.19 & 1.12 & 3.55 \\
\hline DNK & 1.66 & 2.00 & 0.58 & 1.19 & 4.48 & 4.79 & 3.42 & 3.72 & 4.81 & 4.99 & 3.69 & 4.84 \\
\hline ESP & 1.63 & 1.98 & 0.50 & 1.15 & 2.23 & 2.50 & 1.21 & 1.87 & 5.42 & 5.63 & 3.97 & 5.81 \\
\hline $\mathrm{EST}^{\mathrm{b})}$ & 2.66 & 2.98 & 1.47 & 2.36 & 1.79 & 2.03 & 1.16 & 1.49 & 3.59 & 3.94 & 1.60 & 3.69 \\
\hline FIN & 1.64 & 1.99 & 0.56 & 1.18 & 0.89 & 1.05 & 0.15 & 0.89 & 3.96 & 4.11 & 2.76 & 4.25 \\
\hline FRA & 1.79 & 2.14 & 0.80 & 1.25 & 2.10 & 2.26 & 1.30 & 2.03 & 3.45 & 3.65 & 2.56 & 3.44 \\
\hline GBR & 1.73 & 2.09 & 0.67 & 1.18 & 2.66 & 2.91 & 1.76 & 2.18 & 3.58 & 3.82 & 2.31 & 3.71 \\
\hline GRC & 1.67 & 2.01 & 0.56 & 1.20 & 3.17 & 3.44 & 2.03 & 2.78 & 5.95 & 6.20 & 4.42 & 6.20 \\
\hline HUN & 1.67 & 2.02 & 0.56 & 1.21 & 1.80 & 2.02 & 0.81 & 1.70 & 11.65 & 11.92 & 9.91 & 12.08 \\
\hline IRL & 1.66 & 2.01 & 0.56 & 1.20 & 3.23 & 3.34 & 2.17 & 3.29 & 8.32 & 8.40 & 6.84 & 8.91 \\
\hline ITA & 1.68 & 2.03 & 0.60 & 1.17 & 1.46 & 1.69 & 0.41 & 1.43 & 2.98 & 3.23 & 1.60 & 3.28 \\
\hline JPN & 2.12 & 2.21 & 0.75 & 2.68 & 3.06 & 3.08 & 1.97 & 3.59 & -0.63 & -0.54 & -1.94 & -0.07 \\
\hline $\mathrm{LTU}^{\mathrm{a})}$ & 1.89 & 2.26 & 0.70 & 1.41 & -0.24 & -0.16 & -1.00 & 0.24 & 8.56 & 8.66 & 7.15 & 9.30 \\
\hline LUX $^{\mathrm{c})}$ & 2.89 & 3.14 & 1.80 & 2.84 & 2.81 & 2.75 & 1.90 & 3.58 & 6.92 & 6.70 & 6.88 & 7.55 \\
\hline LVA & 1.67 & 2.02 & 0.57 & 1.22 & -0.32 & -0.22 & -1.06 & -0.22 & 9.88 & 9.84 & 9.08 & 10.47 \\
\hline $\mathrm{MLT}^{\mathrm{d})}$ & 3.12 & 3.30 & 2.15 & 3.29 & -2.09 & -2.49 & -3.09 & 0.43 & 3.93 & 3.98 & 1.31 & 5.44 \\
\hline NLD & 1.69 & 2.03 & 0.61 & 1.20 & 3.10 & 3.31 & 2.05 & 2.84 & 3.77 & 3.96 & 2.77 & 3.73 \\
\hline POL & 1.67 & 2.02 & 0.56 & 1.21 & 2.66 & 2.94 & 1.60 & 2.30 & 11.59 & 11.88 & 10.22 & 11.61 \\
\hline PRT & 1.66 & 2.01 & 0.56 & 1.20 & 0.98 & 1.09 & 0.12 & 1.32 & 4.04 & 4.22 & 2.84 & 4.47 \\
\hline ROU & 1.67 & 2.02 & 0.57 & 1.21 & 0.71 & 0.87 & -0.33 & 0.90 & 12.20 & 12.37 & 10.75 & 12.74 \\
\hline SVK & 1.67 & 2.02 & 0.57 & 1.22 & 2.67 & 2.84 & 1.94 & 2.80 & 11.47 & 11.66 & 9.71 & 12.34 \\
\hline SVN & 1.67 & 2.02 & 0.57 & 1.22 & 1.49 & 1.74 & 0.31 & 1.42 & 5.93 & 6.23 & 3.82 & 6.48 \\
\hline SWE & 1.66 & 2.01 & 0.55 & 1.20 & 1.70 & 1.89 & 0.71 & 1.67 & 3.91 & 4.28 & 1.94 & 4.11 \\
\hline TUR & 1.65 & 2.01 & 0.55 & 1.17 & -0.19 & -0.05 & -0.82 & -0.12 & 5.97 & 6.07 & 5.00 & 6.39 \\
\hline USA & 1.24 & 1.76 & 0.08 & 0.56 & -0.38 & 0.14 & -0.75 & -1.26 & 2.08 & 2.43 & 0.66 & 2.13 \\
\hline Average & 1.85 & 2.19 & 0.74 & 1.46 & 1.65 & 1.82 & 0.74 & 1.65 & 5.76 & 5.95 & 4.34 & 6.14 \\
\hline SD & 0.43 & 0.40 & 0.43 & 0.61 & 1.47 & 1.53 & 1.39 & 1.28 & 3.37 & 3.35 & 3.36 & 3.49 \\
\hline
\end{tabular}

See note to Table 1. SD:standard deviation.

Turning our attention to the variation of the growth rates among countries, we find that three measures of foreign $R \& D$ capital stock have, in general, a smaller standard deviation than the domestic R\&D capital stock. For example, the standard deviation of the domestic R\&D capital stock is 3.99 for "all sector", while the corresponding figure of the foreign R\&D capital stock is $0.43(\mathrm{SA}), 1.47(\mathrm{CH})$ and 3.37 (LP). It should be noted that the standard deviation of the SA measure is extremely small, only $11 \%$ of that of the domestic R\&D capital. On the contrary, the LP measure shows the largest 
standard deviation among the three measures. It is about $85 \%$ of that of domestic R\&D capital.

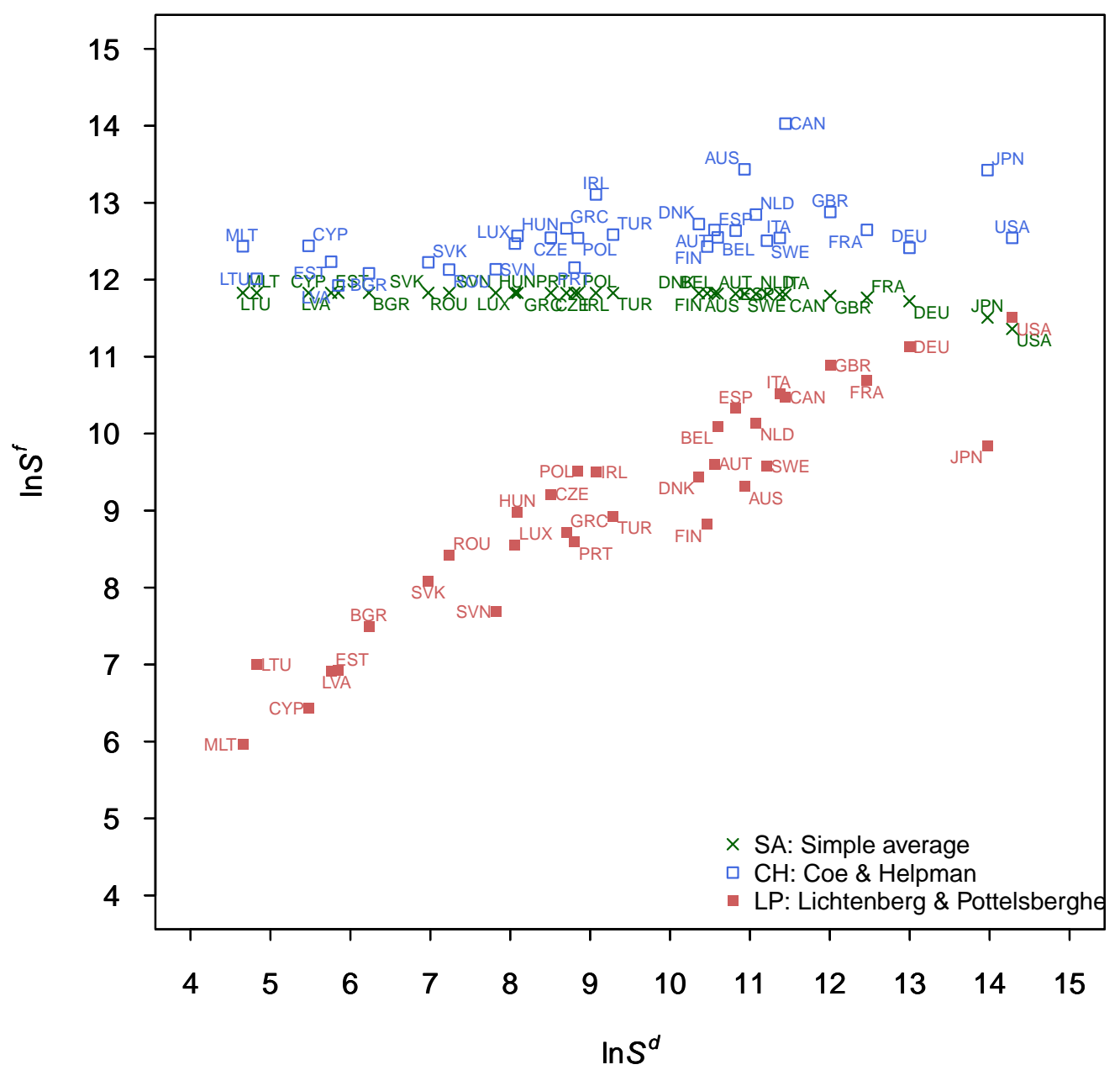

Fig. 1 Scatter diagram of domestic and foreign R\&D stocks in 2007

The description so far is focused on the growth rate of $R \& D$ stocks, but the same discussion holds for the level of $R \& D$ stocks. Figure 1 shows the scatter diagram of domestic and three measures of foreign R\&D capital stock in 2007. We pick the year 2007 as a reference year in this analysis, because it is one year before the start of the financial crisis. As can be seen from the figure, SA and $\mathrm{CH}$ measures show much less variation than the LP measure. Actually, the variances of the three measures are 0.01 (SA), $0.19(\mathrm{CH})$ and 2.01 (LP), respectively, while that of the domestic R\&D capital stock is 6.79 in 2007 . We observe the same tendency in other sample years. As far as 
the between variation is concerned, we can say that LP measure contains much richer information on foreign R\&D capital stock than any other measures. We come back this point in the next section where three measures are compared from the viewpoint of the performance in the estimation of the TFP function.

\subsection{Total Factor Productivity}

Following Coe and Helpman (1995), we estimate an equation for Total Factor Productivity (TFP) in logarithmic form as:

$$
\ln T F P_{i, t}=\ln X_{i, t}-\varphi_{K, t} \ln K_{i, t-1}-\varphi_{L, t} \ln L_{i, t}-\varphi_{I M, t} \ln I M_{i, t},
$$

where $X_{i, t}:$ real gross output of country $i$ in period $t$,

$K_{i, t}:$ real gross capital stock of country $i$ in period $t$,

$L_{i, t}$ : labor input of country $i$ in period $t$,

$I M_{i, t}$ : intermediate input of country $i$ in period $t$ and

$\varphi_{K, t}, \varphi_{L, t}, \varphi_{I M, t}$ cost share of each factor of country $i$ in period $t$.

All the variables in equation (18) are taken from WIOD. Unit of the variables are millions of 1995 US dollar except for labor input that is measured in total working hours in millions of hours. The $\log$ of TFP (lnTFP) at 1996, 2002, 2008 and 2009 as well as average growth rates are presented in Table 3.

The level of TFP depends crucially on the unit of the variables, so the discussion on the level of TFP is less sensible, but as far as the unit of the variables are the same, we can discuss an inter-country and inter-temporal comparison.

At the beginning of the sample period, 1996, countries are clearly divided into two groups at the value of $\ln T F P$ that is unity. There are 9 countries with $\operatorname{lnTFP}$ smaller than 1 and 23 countries with $\ln T F P$ larger than 1 . It should be noted that the growth rates are all positive for low TFP countries, while those for high TFP countries sometime show negative values.

Figure 2 depicts the evolution of $\ln T F P$ by country. The blue lines are for the high TFP country group in 1996 and red lines are for the low TFP country group. Even for this relatively short period, we can conceive the convergence of productivity especially within European countries, maybe due to the European Union. Actually, as is shown at the bottom row in Table 3, the standard deviation of $\ln T F P$ is decreasing, while the average of $\ln T F P$ remains constant during the sample period. It is an interesting research topic to explore the extent to which $R \& D$ spillovers contribute to the convergence of productivity. 
Table 3: $\ln T F P$ and its growth rate

\begin{tabular}{|c|c|c|c|c|c|}
\hline & 1996 & 2002 & 2008 & 2009 & $\begin{array}{l}\text { Growth } \\
\text { rate }(\%)\end{array}$ \\
\hline AUS & 1.39 & 1.41 & 1.37 & 1.35 & -0.31 \\
\hline AUT & 1.80 & 1.71 & 1.62 & - & $-1.46^{\text {a) }}$ \\
\hline BEL & 1.68 & 1.68 & 1.60 & 1.69 & 0.08 \\
\hline BGR & 0.45 & 0.52 & 0.59 & 0.60 & 1.19 \\
\hline CAN & 1.39 & 1.42 & 1.44 & 1.45 & 0.45 \\
\hline CYP & 1.40 & 1.47 & 1.49 & 1.49 & 0.73 \\
\hline CZE & 0.77 & 0.80 & 0.86 & - & $0.68^{\text {a) }}$ \\
\hline DEU & 1.81 & 1.79 & 1.66 & - & $-1.30^{\text {a) }}$ \\
\hline DNK & 1.73 & 1.75 & 1.71 & - & $-0.18^{a)}$ \\
\hline ESP & 1.47 & 1.40 & 1.36 & - & $-0.91^{\text {a) }}$ \\
\hline EST & 0.73 & 0.76 & 0.94 & 0.97 & 1.84 \\
\hline FIN & 1.60 & 1.56 & 1.56 & - & $-0.38^{\text {a) }}$ \\
\hline FRA & 1.61 & 1.62 & 1.61 & - & $-0.06^{a)}$ \\
\hline GBR & 1.58 & 1.68 & 1.68 & - & $0.85^{\text {a) }}$ \\
\hline GRC & 1.14 & 1.31 & 1.39 & 1.43 & 2.18 \\
\hline HUN & 0.80 & 0.85 & 0.90 & - & $0.80^{\text {a) }}$ \\
\hline IRL & 1.39 & 1.29 & 1.41 & - & $0.17^{\text {a) }}$ \\
\hline ITA & 1.52 & 1.42 & 1.43 & - & $-0.79^{\text {a) }}$ \\
\hline JPN & 1.56 & 1.60 & 1.43 & 1.53 & -0.19 \\
\hline LTU & 0.67 & 0.66 & 0.83 & 0.77 & 0.77 \\
\hline LUX & 1.45 & 1.40 & 1.19 & 1.28 & -1.34 \\
\hline LVA & 0.75 & 0.74 & 0.98 & 0.86 & 0.85 \\
\hline MLT & 1.19 & 1.22 & 1.26 & 1.26 & 0.55 \\
\hline NLD & 1.63 & 1.66 & 1.61 & - & $-0.14^{\text {a) }}$ \\
\hline POL & 1.37 & 1.07 & 0.97 & - & $-3.29^{a)}$ \\
\hline PRT & 1.30 & 1.32 & 1.29 & 1.31 & 0.08 \\
\hline ROU & 0.64 & 0.75 & 0.85 & 0.78 & 1.01 \\
\hline SVK & 0.59 & 0.61 & 0.69 & 0.71 & 0.89 \\
\hline SVN & 1.47 & 1.43 & 1.41 & 1.47 & 0.03 \\
\hline SWE & 1.68 & 1.74 & 1.66 & - & $-0.13^{\text {a) }}$ \\
\hline TUR & 0.73 & 0.80 & 0.93 & 0.90 & 1.27 \\
\hline USA & 1.62 & 1.71 & 1.66 & 1.68 & 0.46 \\
\hline Average & 1.28 & 1.29 & 1.29 & & \\
\hline SD & 0.41 & 0.40 & 0.33 & & \\
\hline
\end{tabular}

Data source: Socio Economic Account in WIOD.

Note: Growth rate for superscript a) indicates the sample period is 1996 - 2008. 


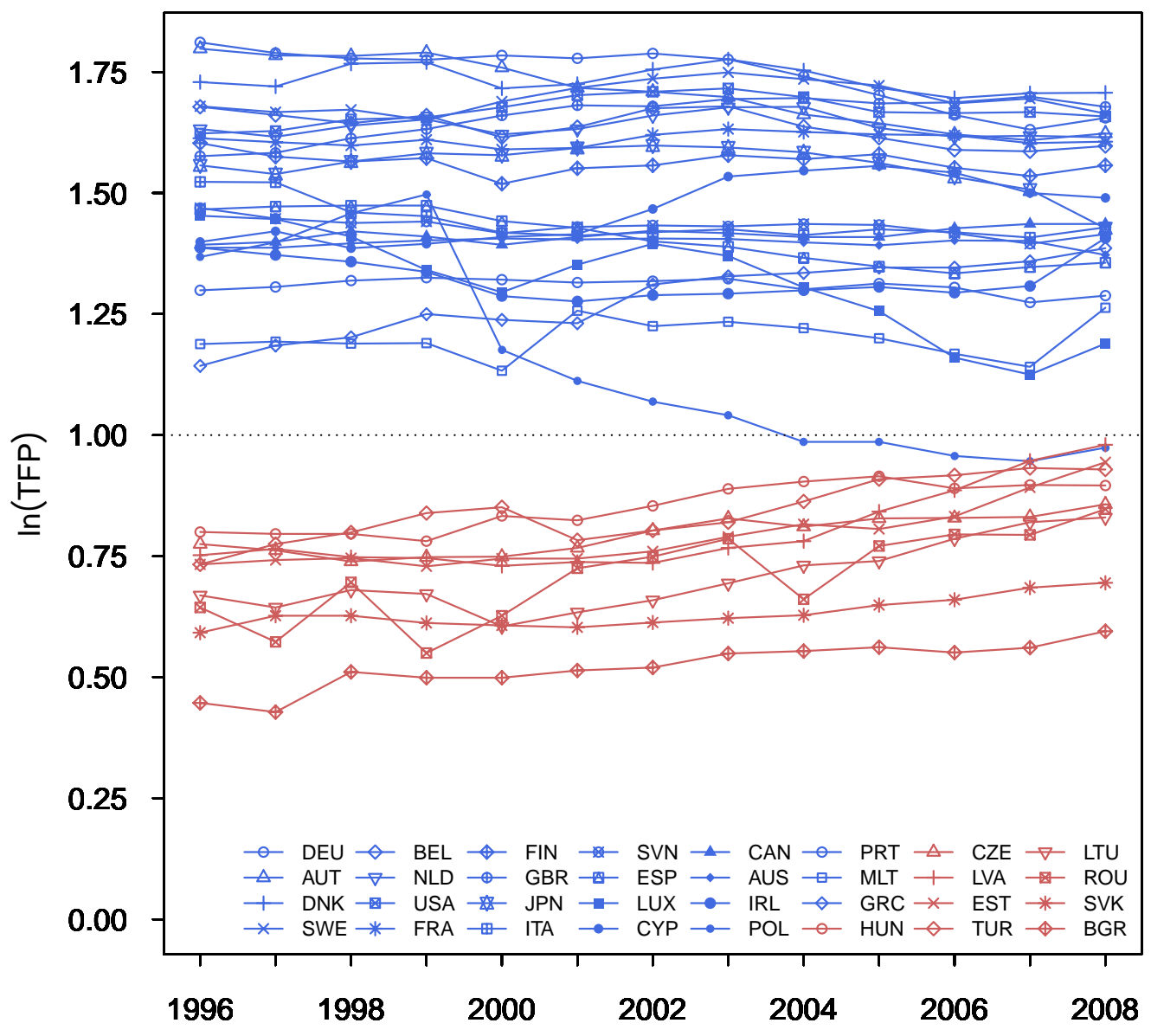

Fig. 2 Comparison of $\ln T F P$ over time by country

\section{Estimation Results}

Next we present the estimation results of the TFP function and the R\&D investment function using the panel data of 32 countries from 1995 to 2009.

\subsection{Estimation Results of the TFP Function}

In Section 3 we specify the production function as a Cobb-Douglas type. We modify the production function in estimation so that the dependent variable is the logarithm of aggregate TFP or 


$$
\ln T F P_{i t}=\varphi_{0}+\varphi_{1} \ln S_{i, t-1}^{d}+\varphi_{2} \ln S_{i, t-1}^{f}+v_{i}+u_{i t}
$$

where $v_{i}$ : country-specific term,

$u_{i t}$ : disturbance term.

As is discussed in Section 2, one of our special features is to divide the R\&D stock of all sectors into three sectoral (business, government and education) stocks. Therefore the TFP function is estimated by using each of the sectoral R\&D stocks as well as the aggregate $R \& D$ stock as independent variable. In this way we can see the relative importance of each sectoral R\&D stock in explaining the aggregate TFP by this estimation exercise. The R\&D stock is constructed in three different ways, as is explained in the previous section and each $\mathrm{R} \& \mathrm{D}$ stock is characterized by its own weighting scheme. We evaluate three $R \& D$ stock measures from the viewpoint of explanatory power and statistical significance.

Equation (19) is estimated by both a Fixed Effects (FE) model as well as a Random Effects (RE) model and the preferred model is chosen by a Hausman specification test. We add year dummies to the explanatory variables in the estimation of the models. Table 4 shows the estimation results. The first panel shows the results where R\&D stock of all sectors is used. Each column corresponds to three different R\&D stock measures: simple average (SA), $\mathrm{CH}$ weight $(\mathrm{CH})$ and $\mathrm{LP}$ weight $(\mathrm{LP})$. In terms of explanatory power, SA is highest, followed by the LP and $\mathrm{CH}$ specifications. The coefficient estimate of the domestic $R \& D$ stock is significantly positive, irrespective of the stock measure, but that of the foreign R\&D stock differs considerably among the three stock measures. The coefficient estimate of the foreign stock is insignificant in SA. It is significantly positive in the LP, while it is significantly negative in the $\mathrm{CH}$ models. It is quite unlikely that the foreign stock has significantly negative effects on domestic TFP. Therefore, judging from the explanatory power and statistical significance of the coefficient estimates of the three foreign R\&D stock measures, the LP stock measure outperforms the other measures. The TFP elasticities in terms of the domestic and foreign stocks in the LP measure are 0.07 and 0.08 , respectively. These values are well within the range of other studies.

Next we compare the relative performance of sectoral R\&D stocks in explaining the economy-wide TFP. The second to fourth panel corresponds to the results where we use the R\&D stocks of the business, government and education sectors, respectively. The estimation results based on the sectoral stocks share common characteristics. First, the $\mathrm{SA}$ and LP measures outperform the $\mathrm{CH}$ measure in terms of explanatory power. Higher 
explanatory power of the LP measures is due to the large between-variations of the foreign R\&D stock, as was seen in Figure 1. Secondly, the coefficient estimate of the foreign stock is insignificant in the SA specification, while it is significantly positive in the LP and significantly negative in the $\mathrm{CH}$ models. These findings indicate that the LP measure outperforms the other measures uniformly. Therefore, in what follows, we adopt the LP measure of the foreign R\&D stock as explanatory variable both in TFP function and $R \& D$ investment function.

Table 4: Estimation results of the TFP function

\begin{tabular}{|c|c|c|c|c|c|}
\hline & & & $\begin{array}{l}(1) \\
\text { SA } \\
\end{array}$ & $\begin{array}{l}(2) \\
\mathrm{CH} \\
\end{array}$ & $\begin{array}{l}(3) \\
\text { LP } \\
\end{array}$ \\
\hline \multirow[t]{4}{*}{ (1) } & All sectors & $\ln S^{d}$ & $0.0882(6.29) * *$ & $0.0891(6.93)^{* *}$ & $0.0650(4.83)^{* *}$ \\
\hline & & $\ln S^{f}$ & $0.0200(0.05)$ & $-0.1324(3.38)^{* *}$ & $0.0774(4.81)^{* *}$ \\
\hline & & $R^{2}\left(\chi^{2}\right)$ & $0.5360(3.70)$ & $0.5075(9.00)$ & $0.5188(8.55)$ \\
\hline & & & $\mathrm{RE}$ & $\mathrm{RE}$ & $\mathrm{RE}$ \\
\hline \multirow[t]{4}{*}{ (2) } & Business & $\ln S^{d B}$ & $0.0565(6.05)^{* *}$ & $0.0561(6.37)^{* *}$ & $0.0460(5.20)^{* * *}$ \\
\hline & sector & $\ln S^{f B}$ & $-0.1778(0.43)$ & $-0.1082(2.84) * *$ & $0.0822(5.28)^{* *}$ \\
\hline & & $R^{2}\left(\chi^{2}\right)$ & $0.5056(8.36)$ & $0.4781(16.2)$ & 0.5105 (3.16) \\
\hline & & & $\mathrm{RE}$ & $\mathrm{RE}$ & $\mathrm{RE}$ \\
\hline \multirow[t]{4}{*}{ (3) } & Government & $\ln S^{d G}$ & $0.0621(3.77)^{* *}$ & $0.0630(4.22)^{* *}$ & $0.0333(2.13)^{*}$ \\
\hline & sector & $\ln S^{f G}$ & $-0.1123(0.25)$ & $-0.1294(3.00)^{* *}$ & $0.0889(5.19)^{* *}$ \\
\hline & & $R^{2}\left(\chi^{2}\right)$ & $0.4267(9.82)$ & $0.3564(23.8)$ & 0.4599 (1.74) \\
\hline & & & $\mathrm{RE}$ & $\mathrm{RE}$ & $\mathrm{RE}$ \\
\hline \multirow[t]{4}{*}{ (4) } & Education & $\ln S^{d E}$ & $0.0876(7.42)^{* *}$ & $0.0905(8.11)^{* *}$ & $0.0627(4.67)^{* * *}$ \\
\hline & sector & $\ln S^{f E}$ & $-0.0289(0.13)$ & $-0.1735(3.97)^{* *}$ & $0.0597(3.31)^{* *}$ \\
\hline & & $R^{2}\left(\chi^{2}\right)$ & $0.5475(2.23)$ & $0.5236(8.54)$ & $0.5439(0.99)$ \\
\hline & & & $\mathrm{RE}$ & $\mathrm{RE}$ & $\mathrm{RE}$ \\
\hline \multirow[t]{8}{*}{ (5) } & 3 individual & $\ln S^{d B}$ & $0.0344(2.97)^{* *}$ & $0.0294(2.58)^{* *}$ & $0.0366(3.11)^{* *}$ \\
\hline & sectors & $\ln S^{d G}$ & $-0.0228(1.11)$ & $-0.0246(1.27)$ & $-0.0303(1.59)$ \\
\hline & together & $\ln S^{d E}$ & $0.0723(4.30)^{* *}$ & $0.0771(4.79) * *$ & $0.0542(2.81)^{* * *}$ \\
\hline & & $\ln S^{f B}$ & $0.3087(0.42)$ & $-0.1026(0.46)$ & $-0.0702(0.43)$ \\
\hline & & $\ln S^{f G}$ & $0.0415(0.06)$ & 0.2762 (1.07) & $-0.2076(1.47)$ \\
\hline & & $\ln S^{f E}$ & $-0.1735(0.61)$ & $-0.3341(2.46)^{*}$ & $0.3324(2.43)^{*}$ \\
\hline & & $R^{2}\left(\chi^{2}\right)$ & 0.5804 (7.94) & $0.5492(14.4)$ & $0.5979(11.5)$ \\
\hline & & & $\mathrm{RE}$ & $\mathrm{RE}$ & $\mathrm{RE}$ \\
\hline
\end{tabular}

Note: The figures in parentheses are the $t$-values in absolute values of coefficients for fixed effects model estimation and $\mathrm{z}$-values for random effects model estimation. $R^{2}$ is the overall coefficient of determination. $\chi^{2}$ is for the Hausman test of null hypothesis that random effects model is valid. RE and FE below $\chi^{2}$ indicate the corresponding result is estimated by random effects model and fixed effects model respectively. Asterisks $*$ and $* *$ indicate that the corresponding statistics are significant at the 5\% and $1 \%$ level, respectively. The number of observations is 418 for all cases. Coefficients for time dummies and constant term are omitted to save space. 
No one will disagree that the $R \& D$ stock in each sector has some positive contribution to the economy-wide TFP, but there will be much dispute about the relative contribution of each sectoral stock to aggregate TFP. Comparing the explanatory power of the sectoral R\&D stocks in Table 4, the education stock has the highest explanatory power, followed by the business and the government stock, irrespective of the stock measures. This is a bit surprising since the business sector supposedly plays an important role in research activities and most of the studies use the R\&D stock of business sector alone.

We include all of the three sectoral stocks as explanatory variables to settle down the dispute. The estimation results are shown in the fifth panel of Table 4. The coefficient estimate of the domestic government $R \& D$ stock is negative. None of the coefficient estimates of the foreign sectoral stock is significantly positive except for the education stock of LP measure. Failure to obtain stable estimates of the sectoral contribution to the aggregate TFP stems from multicollinearity among the sectoral stocks. In fact the correlation coefficients among logarithmic domestic sectoral stocks as well as foreign sectoral stocks all exceed 0.95. To overcome this problem, we construct a synthetic R\&D stock by applying principal components analysis to the logs of domestic and foreign sectoral R\&D stocks. The new synthetic stock is a linear combination of the three sectoral $R \& D$ stocks based on the eigenvector of the covariance matrix of the R\&D stocks. Eigenvector corresponding to the first principal component, coefficient of each sectoral stock, is shown by year in Table 5.

Table 5: Coefficients of the first principal component

\begin{tabular}{ccccccc}
\hline & \multicolumn{3}{c}{$(1)$} & $(2)$ & $(3)$ & \multicolumn{2}{c}{$(4)$} & $(5)$ & $(6)$ \\
& \multicolumn{3}{c}{ Domestic R\&D } & \multicolumn{3}{c}{ Foreign R\&D: LP } \\
\cline { 2 - 7 } & Bus. & Gov. & Edu. & Bus. & Gov. & Edu. \\
& $\omega_{d B}$ & $\omega_{d G}$ & $\omega_{d E}$ & $\omega_{f B}$ & $\omega_{f G}$ & $\omega_{f E}$ \\
\hline 1995 & 0.6216 & 0.5038 & 0.5998 & 0.5822 & 0.5724 & 0.5775 \\
1996 & 0.6582 & 0.4838 & 0.5768 & 0.5826 & 0.5717 & 0.5777 \\
1997 & 0.6583 & 0.4823 & 0.5779 & 0.5830 & 0.5720 & 0.5770 \\
1998 & 0.6683 & 0.4838 & 0.5651 & 0.5833 & 0.5742 & 0.5745 \\
1999 & 0.6711 & 0.4818 & 0.5635 & 0.5834 & 0.5743 & 0.5742 \\
2000 & 0.6507 & 0.4807 & 0.5878 & 0.5840 & 0.5740 & 0.5739 \\
2001 & 0.6426 & 0.4856 & 0.5927 & 0.5844 & 0.5743 & 0.5733 \\
2002 & 0.6408 & 0.5026 & 0.5804 & 0.5835 & 0.5744 & 0.5741 \\
2003 & 0.6404 & 0.5037 & 0.5798 & 0.5837 & 0.5749 & 0.5734 \\
2004 & 0.6388 & 0.5062 & 0.5794 & 0.5840 & 0.5756 & 0.5724 \\
2005 & 0.6338 & 0.5125 & 0.5794 & 0.5847 & 0.5763 & 0.5710 \\
2006 & 0.6317 & 0.5166 & 0.5780 & 0.5856 & 0.5754 & 0.5709 \\
2007 & 0.6298 & 0.5208 & 0.5763 & 0.5857 & 0.5764 & 0.5698 \\
2008 & 0.6302 & 0.5250 & 0.5721 & 0.5854 & 0.5772 & 0.5693 \\
2009 & 0.6335 & 0.5261 & 0.5674 & 0.5862 & 0.5767 & 0.5690 \\
\hline
\end{tabular}


It turns out that in all cases, more than $90 \%$ of the total variance of the original sectoral R\&D capital stocks is explained by the first principal component. Accordingly we only use the first principal component. The coefficient of each R\&D stock is quite stable over time for both domestic and foreign stocks. As for the domestic R\&D stock, the business sector stock has the largest coefficient (0.6216-0.6711), followed by the education sector stock $(0.5674-0.5998)$ and the government sector stock (0.4807-0.5261). The coefficients of three sectors are quite close for the foreign stock. They hover around 0.56 to 0.58 . Table 6 shows the estimation result of the TFP function based on this synthetic R\&D stock. The estimation results are quite satisfactory and the coefficient estimates of both domestic and foreign stocks are significantly positive. The TFP elasticities of business, government and education domestic R\&D stock are 0.025 $(=0.0396 \times 0.6298), 0.021(=0.0396 \times 0.5208)$ and $0.023(=0.0396 \times 0.5763)$, respectively, in 2007. The corresponding figures for the foreign stock is $0.023(=0.0391 \times 0.5857)$, $0.023(=0.0391 \times 0.5764)$, and $0.022(=0.0391 \times 0.5698)$, respectively, in 2007 .

Table 6: Estimation result of TFP function (PCA)

\begin{tabular}{lll}
\hline$Z^{d}$ & 0.0396 & $(5.07)^{* *}$ \\
$Z^{f-L P}$ & 0.0391 & $(4.02)^{* *}$ \\
$R^{2}\left(\chi^{2}\right)$ & 0.5188 & $(3.63)$ \\
& \multicolumn{2}{c}{$\mathrm{RE}$} \\
\hline
\end{tabular}

See note of Table 4.

\subsection{Estimation Results of the R\&D Investment Function}

Now we move on to estimation of $R \& D$ investment function. $R \& D$ investment function to be estimated is specified as:

$$
\begin{aligned}
\ln R_{i t}=\mu_{0} & +\mu_{1} \ln S_{i, t-1}^{d}+\mu_{2} \ln S_{i, t-1}^{f}+\mu_{3} \Delta \ln X_{i t}+\mu_{4} \ln D_{i, t-1}+v_{i} \\
& +u_{i t}
\end{aligned}
$$

where $v_{i}$ : country-specific term and

$u_{i t}$ : disturbance term.

Equation (20) is a standard $R \& D$ investment function where $R \& D$ investment depends on domestic and foreign $R \& D$ stocks at the end of the previous year, growth rate of gross output and debt outstanding at the end of the previous year. ${ }^{10}$ The R\&D investment function is estimated for 'all sectors' together and each separate sector. Accordingly the dependent variable is R\&D real investment of 'all sectors' and each sector. We use two R\&D stocks as the independent variable alternatively. One is the

${ }^{10}$ Internal funds are also a popular explanatory variable of R\&D investment. We also included gross sectoral saving as explanatory variable, but it turns out that it picked up negative sign. 
sectoral stock corresponding to sectoral estimation. The other is the synthetic stock constructed by the principal component analysis. Year dummies are added to the explanatory variables.

Table 7: Estimation results of the R\&D investment function

\begin{tabular}{|c|c|c|c|c|}
\hline \multirow[t]{5}{*}{ (1) } & \multirow[t]{5}{*}{ All sectors } & $\ln S^{d}$ & 0.6739 & $(17.3)^{* *}$ \\
\hline & & $\ln S^{f L P}$ & 0.1252 & $(3.76) * *$ \\
\hline & & $\ln D$ & 0.3505 & $(8.41)^{* *}$ \\
\hline & & $\Delta \ln X$ & 0.6120 & $(3.39)^{* * *}$ \\
\hline & & $R^{2}\left(\chi^{2}\right)$ & 0.9914 & $\begin{array}{l}(71.1)^{* *} \\
\mathrm{FE}\end{array}$ \\
\hline \multirow[t]{5}{*}{ (2) } & \multirow[t]{5}{*}{ Business sector } & $\ln S^{d B}$ & 0.7975 & $(27.6) * *$ \\
\hline & & $\ln S^{f B-L P}$ & -0.0468 & $(0.85)$ \\
\hline & & $\ln D$ & 0.2810 & $(5.55)^{* *}$ \\
\hline & & $\Delta \ln X$ & 0.8890 & $(2.29)^{*}$ \\
\hline & & $R^{2}\left(\chi^{2}\right)$ & 0.9892 & $\begin{array}{l}(16.8) \\
\mathrm{RE}\end{array}$ \\
\hline \multirow[t]{5}{*}{ (3) } & \multirow[t]{5}{*}{ Government sector } & $\ln S^{d G}$ & 0.8598 & $(27.8)^{* * *}$ \\
\hline & & $\ln S^{f G-L P}$ & 0.1799 & $(4.42)^{* * *}$ \\
\hline & & $\ln D$ & 0.0230 & $(0.80)$ \\
\hline & & $\Delta \ln X$ & 0.4345 & $(1.28)$ \\
\hline & & $R^{2}\left(\chi^{2}\right)$ & 0.9897 & $\begin{array}{l}(17.7) \\
\text { RE }\end{array}$ \\
\hline \multirow[t]{5}{*}{ (4) } & \multirow[t]{5}{*}{ Education sector } & $\ln S^{d E}$ & 1.0770 & $(20.4)^{* *}$ \\
\hline & & $\ln S^{f E-L P}$ & 0.1972 & $(3.51)^{* *}$ \\
\hline & & $\ln D$ & 0.0352 & $(0.78)$ \\
\hline & & $\Delta \ln X$ & 0.8818 & $(3.08)^{* * *}$ \\
\hline & & $R^{2}\left(\chi^{2}\right)$ & 0.9934 & $\begin{array}{l}(31.0)^{*} \\
\mathrm{FE}\end{array}$ \\
\hline
\end{tabular}

See note for Table 4 . The number of observations is 392 for all sectors and the business sector and 403 for the government and education sectors.

Table 7 shows the estimation results of the R\&D investment model, where Fixed Effects or Random Effects are chosen by the Hausman specification test. In estimation we use the sectoral stocks as explanatory variables. The estimation results share the characteristics common to each sectoral case. First, the domestic stock has a significantly positive effect on $R \& D$ investment. Second, the foreign stock also exerts a significantly positive effect on domestic R\&D investment except for the business sector. In the business sector equation the coefficient estimate of foreign stock is negative, 
though insignificant. ${ }^{11}$ Third, output growth rate has a significantly positive effect on R\&D activities except for government sector. Fourth, debt outstanding has significantly positive effects on R\&D investment except for government and education sectors. This result indicates that debt outstanding represents a proxy of debt capacity rather than a borrowing constraint.

Table 8 shows the estimation results where the synthetic stock is used. The estimation results remain essentially unaltered.

Table 8: Estimation results of the R\&D investment function (PCA)

$\begin{array}{llll} & \\ Z^{d} & 0.4120 & (28.1)^{* *} \\ Z^{f-L P} & 0.0135 & (0.75) \\ & \ln D & 0.2819 & (9.00)^{* *} \\ & \Delta \ln \mathrm{X} & 0.3546 & (1.88) \\ & R^{2}\left(\chi^{2}\right) & 0.9935 & (24.5) \\ & & \mathrm{RE}\end{array}$
(2) Business sector $\quad Z^{d} \quad 0.8586(19.7)^{* *}$
$Z^{f-L P} \quad-0.1118(2.65)^{* *}$
$\ln D \quad 0.4174(5.53)^{* * *}$
$\Delta \ln \mathrm{X} \quad 1.0979(2.77)^{* *}$
$R^{2}\left(\chi^{2}\right) \quad 0.9761(74.0)^{* *}$
$\mathrm{FE}$

(3) Government sector

\begin{tabular}{lrl}
$Z^{d}$ & 0.0238 & $(0.56)$ \\
$Z^{f-L P}$ & 0.1937 & $(4.80)^{* *}$ \\
$\ln D$ & 0.1251 & $(2.12)^{*}$ \\
$\Delta \ln X$ & -0.2200 & $(0.57)$ \\
$R^{2}\left(\chi^{2}\right)$ & 0.9153 & $(146 .)^{* *}$ \\
& \multicolumn{2}{c}{$\mathrm{FE}$}
\end{tabular}

(4) Education sector $\quad Z^{d} \quad 0.3576(8.43)^{* *}$

$$
\begin{array}{lll}
Z^{f-L P} & 0.3435 & (8.52)^{* *} \\
\ln D & 0.1970 & (3.33)^{* *} \\
\Delta \ln \mathrm{X} & 0.7270 & (1.88) \\
R^{2}\left(\chi^{2}\right) & 0.9398 & (75.8)^{* *} \\
& \multicolumn{2}{c}{\mathrm{FE}}
\end{array}
$$

See notes to Table 7 .

\footnotetext{
${ }^{11}$ Bloom et al. (2013) show theoretically that a firm's R\&D is positively related to the R\&D by other firms in the same technology space as long as diminishing returns in knowledge production are not too strong and that a firm's $R \& D$ is negatively related to the R\&D by other firms in the same technology space when diminishing returns in knowledge production are strong.
} 


\section{Social and Private Returns on R\&D under International R\&D Spillovers}

This section computes marginal social returns (MSR) and marginal private returns (MPR) on R\&D, based on the estimation results of Section 5. Comparison of social returns with private returns on $R \& D$ gives important information about the socially optimal level of $\mathrm{R} \& \mathrm{D}$ relative to the observed level.

We compute social returns and private returns on R\&D for 'all sectors' as well as the business sector. Social and private returns are evaluated in $2007 .{ }^{12}$ In computing returns on R\&D for 'all sectors', we use the coefficient estimates of domestic and foreign R\&D stock of the TFP function for 'all sectors' based on the LP measure (the first panel of Table 4) and the coefficient estimates of the domestic and foreign stocks of the R\&D investment function for 'all sectors' (Table 7). The information about the coefficient estimates used for computation is summarized in Table 9.

Table 9. Parameters for the simulation analysis

\begin{tabular}{llrr}
\hline & & All sectors & Business sector \\
\hline TFP function & $\omega^{\mathrm{d}}$ & 1 & 0.6298 \\
& $\omega^{\mathrm{f}}$ & 1 & 0.5857 \\
& $\psi_{1}$ & 0.0650 & \\
& $\psi_{2}$ & 0.0774 & \\
& $\psi_{1}$ (PCA) & & 0.0396 \\
& $\psi_{2}$ (PCA) & & 0.0391 \\
\hline R\&D investment & $\mu_{1}$ & 0.6739 & \\
function & $\mu_{2}$ & 0.1252 & \\
& $\mu_{1}$ (PCA) & & 0.8586 \\
& $\mu_{2}$ (PCA) & & -0.1118 \\
\hline
\end{tabular}

The $i$-th column of the matrix of $(\mathbf{I}-\mathbf{\Psi})^{\mathbf{- 1}}$ in eq. (11) gives important information about the extent to which a one percent exogenous change in R\&D stock of country $i$ gives rise to changes in R\&D stock of own and other countries in steady state in percent terms. This matrix is an important ingredient to determine the magnitude of $R \& D$ spillovers. The matrix of $(\mathbf{I}-\boldsymbol{\Psi})^{\mathbf{- 1}}$ is available upon request. The diagonal elements of this matrix, own elasticity of $R \& D$ stock change in steady state, are quite stable around 3 across countries. In other words, one percent exogenous change in R\&D stock of country $i$ eventually raises its own stock by $3 \%$.

The off-diagonal elements measure the magnitude of spillovers to R\&D stocks of other countries. The spillovers are substantial for Germany, U.S., France, Japan and the

12 Saito and Tokutsu (2015) demonstrate that world trade structure drastically changed after the Lehman crisis in 2008. Therefore we choose 2007 as a benchmark year to evaluate social and private returns. 
Netherlands. The number of the off-diagonal elements that exceeds 0.1 is $31,31,30,25$ and 20 for Germany, U.S., France, Japan and the Netherlands, respectively. Table 10 shows the marginal social returns (column 2) and marginal private returns (column 3). The upper panel corresponds to the figures for less R\&D intensive countries and the lower panel corresponds to those for R\&D intensive countries. ${ }^{13}$

Table 10: Marginal social and private returns: all sectors

\begin{tabular}{|c|c|c|c|c|c|c|}
\hline & $\begin{array}{c}(1) \\
\mathrm{R} \& \mathrm{D} / \mathrm{X} \\
(\%)\end{array}$ & $\begin{array}{c}(2) \\
\text { MSR }\end{array}$ & $\begin{array}{c}(3) \\
\text { MPR }\end{array}$ & $\begin{array}{c}\text { (4) } \\
\text { MSR } \\
\text { (elasticity) } \\
\end{array}$ & $\begin{array}{c}\text { (5) } \\
\text { MPR } \\
\text { (elasticity) }\end{array}$ & $\begin{array}{c}\text { (6) } \\
\text { MSR/MPR }\end{array}$ \\
\hline LTU & 0.49 & 9.0766 & 13.2110 & 0.0447 & 0.0650 & 0.6871 \\
\hline MLT & 0.99 & 4.6572 & 6.5588 & 0.0462 & 0.0650 & 0.7101 \\
\hline ROU & 1.03 & 5.5805 & 6.3090 & 0.0575 & 0.0650 & 0.8845 \\
\hline CYP & 1.05 & 5.4895 & 6.1680 & 0.0579 & 0.0650 & 0.8900 \\
\hline TUR & 1.07 & 5.4569 & 6.0615 & 0.0586 & 0.0651 & 0.9003 \\
\hline BGR & 1.15 & 5.2750 & 5.6627 & 0.0606 & 0.0650 & 0.9315 \\
\hline SVK & 1.32 & 4.3197 & 4.9464 & 0.0569 & 0.0651 & 0.8733 \\
\hline POL & 1.44 & 4.2107 & 4.5456 & 0.0605 & 0.0653 & 0.9263 \\
\hline LVA & 1.69 & 3.8555 & 3.8490 & 0.0651 & 0.0650 & 1.0017 \\
\hline EST & 1.74 & 3.6332 & 3.7349 & 0.0633 & 0.0651 & 0.9728 \\
\hline GRC & 1.83 & 3.6358 & 3.5490 & 0.0666 & 0.0650 & 1.0245 \\
\hline $\mathrm{CZE}$ & 2.02 & 3.7356 & 3.2437 & 0.0754 & 0.0655 & 1.1517 \\
\hline HUN & 2.24 & 3.6397 & 2.9102 & 0.0816 & 0.0653 & 1.2507 \\
\hline PRT & 2.29 & 3.4269 & 2.8475 & 0.0785 & 0.0652 & 1.2035 \\
\hline IRL & 2.70 & 3.3266 & 2.4267 & 0.0899 & 0.0656 & 1.3709 \\
\hline ESP & 2.72 & 3.0375 & 2.4312 & 0.0825 & 0.0660 & 1.2494 \\
\hline LUX & 3.11 & 3.3722 & 2.0989 & 0.1048 & 0.0652 & 1.6066 \\
\hline ITA & 3.22 & 2.8195 & 2.0732 & 0.0907 & 0.0667 & 1.3600 \\
\hline SVN & 3.60 & 3.2058 & 1.8116 & 0.1153 & 0.0652 & 1.7696 \\
\hline AUS & 4.95 & 2.2259 & 1.3429 & 0.1101 & 0.0664 & 1.6576 \\
\hline BEL & 5.15 & 3.0963 & 1.3206 & 0.1595 & 0.0680 & 2.3446 \\
\hline GBR & 5.27 & 2.3425 & 1.2902 & 0.1235 & 0.0680 & 1.8157 \\
\hline NLD & 5.80 & 2.9024 & 1.1851 & 0.1683 & 0.0687 & 2.4491 \\
\hline CAN & 5.83 & 2.6309 & 1.2100 & 0.1534 & 0.0705 & 2.1743 \\
\hline AUT & 6.44 & 2.7870 & 1.0483 & 0.1796 & 0.0676 & 2.6586 \\
\hline FRA & 6.98 & 2.1953 & 1.0022 & 0.1532 & 0.0699 & 2.1905 \\
\hline DNK & 7.35 & 2.5008 & 0.9110 & 0.1837 & 0.0669 & 2.7449 \\
\hline DEU & 7.83 & 2.4778 & 0.9926 & 0.1939 & 0.0777 & 2.4961 \\
\hline USA & 8.10 & 1.3580 & 0.9472 & 0.1101 & 0.0768 & 1.4338 \\
\hline FIN & 8.75 & 2.4436 & 0.7652 & 0.2139 & 0.0670 & 3.1932 \\
\hline JPN & 10.49 & 1.3142 & 0.6929 & 0.1379 & 0.0727 & 1.8966 \\
\hline SWE & 10.92 & 2.4087 & 0.6310 & 0.2630 & 0.0689 & 3.8175 \\
\hline \multicolumn{7}{|c|}{ Average: } \\
\hline \multirow{2}{*}{\multicolumn{2}{|c|}{$\begin{array}{l}\text { low } \mathrm{R} \& \mathrm{D} / \mathrm{X} \text { countries } \\
\text { high } \mathrm{R} \& \mathrm{D} / \mathrm{X} \text { countries }\end{array}$}} & 4.5223 & 4.9034 & 0.0654 & 0.0652 & 1.0018 \\
\hline & & 2.5050 & 1.2077 & 0.1538 & 0.0691 & 2.2255 \\
\hline
\end{tabular}

${ }^{13} \mathrm{R} \& \mathrm{D}$ intensive country is defined as the country whose ratio of $\mathrm{R} \& \mathrm{D}$ stock to gross output is above the median of 32 countries in 2007. 
The MSRs are larger than the MPRs for all countries in the R\&D intensive group. In contrast the MSRs are lower than the MPRs in half of the countries of the less R\&D intensive group, although the levels of both MSRs and MPRs in the less R\&D intensive group are higher than that in the R\&D intensive group. The average MSR and MPR of the R\&D intensive group are $251 \%$ and $121 \%$, respectively and the average MSR and MPR of the less R\&D intensive group are $452 \%$ and $490 \%$, respectively. When the magnitude of spillovers is evaluated in terms of elasticities rather than marginal changes, the difference between the $R \& D$ intensive group and the less $R \& D$ intensive group becomes more conspicuous. There is no discernible difference of the private returns in terms of elasticity between the $R \& D$ intensive group and the less $R \& D$ intensive group. It ranges from 0.065 to 0.073 . However, the social returns in terms of elasticity for $\mathrm{R} \& \mathrm{D}$ intensive group exceeds 0.1 in all countries, while those for the less $\mathrm{R} \& \mathrm{D}$ intensive group are less than 0.1 in all countries and the social returns in terms of elasticity are lower than the private returns in terms of elasticity in some countries.

Now we compute the MSR and MPR on R\&D for the business sector. We use the coefficient estimates of domestic and foreign R\&D stock of the business sector in the TFP function with the synthetic R\&D stock (Table 6). As for the information about $R \& D$ investment behavior, we use the coefficient estimates of the domestic and foreign stocks of the business sector in the $R \& D$ investment function with the synthetic $R \& D$ stock (Table 8). The information about the coefficient estimates used for our computations is also shown in Table $9 .^{14}$

The R\&D investment behavior of the business sector differs from that of all sectors in that $R \& D$ stock of foreign sector has negative effects on domestic $R \& D$ investment. The matrix of $(\mathbf{I}-\boldsymbol{\Psi})^{\mathbf{- 1}}$, available upon request, reflects this difference in investment behavior. The diagonal elements of this matrix are stable around 2.1 across countries, slightly smaller than those in the 'all sectors' case. Most of the off-diagonal elements are negative, which implies that an exogenous increase in R\&D stock of one country reduces the $R \& D$ stocks of other countries. However, this negative effect of $R \& D$ spillovers is not large except for Germany where the number of the off-diagonal elements that exceeds 0.1 in absolute value is 15 .

Table 11 shows the marginal social returns (column 2) and marginal private returns (column 3). The upper panel corresponds to the figures for less R\&D intensive countries and the lower panel corresponds to those for R\&D intensive countries. The MSRs exceed the MPRs in all the countries. It is because an exogenous increase in R\&D stock

${ }^{14}$ See Appendix $\mathrm{C}$ for the detailed procedure of computing MSR and MPR on R\&D for the business sector. 
in one country decreases the R\&D stocks of other countries, but the increase in output arising from initial increase in R\&D stock is much larger than the decrease in output resulting from the subsequent decrease in $R \& D$ stock of other countries.

Table 11: Marginal social returns and private returns: Business sector

\begin{tabular}{|c|c|c|c|c|c|c|}
\hline & $\begin{array}{c}(1) \\
\mathrm{R} \& \mathrm{D} / \mathrm{X} \\
(\%)\end{array}$ & $\begin{array}{c}(2) \\
\text { MSR }\end{array}$ & $\begin{array}{l}\text { (3) } \\
\text { MPR }\end{array}$ & $\begin{array}{c}\text { (4) } \\
\text { MSR } \\
\text { (elasticity) }\end{array}$ & $\begin{array}{c}\text { (5) } \\
\text { MPR } \\
\text { (elasticity) }\end{array}$ & $\begin{array}{c}\text { (6) } \\
\text { MSR/MPR }\end{array}$ \\
\hline$\overline{\text { LTU }}$ & 0.10 & 28.9882 & 25.1411 & 0.0288 & 0.0249 & 1.1530 \\
\hline CYP & 0.22 & 12.7980 & 11.3594 & 0.0281 & 0.0249 & 1.1266 \\
\hline BGR & 0.31 & 10.7914 & 7.9439 & 0.0339 & 0.0249 & 1.3585 \\
\hline TUR & 0.34 & 8.2312 & 7.3779 & 0.0278 & 0.0249 & 1.1157 \\
\hline POL & 0.47 & 7.2077 & 5.2743 & 0.0341 & 0.0249 & 1.3666 \\
\hline MLT & 0.53 & 9.7627 & 4.7084 & 0.0517 & 0.0249 & 2.0735 \\
\hline GRC & 0.55 & 4.9469 & 4.5240 & 0.0273 & 0.0249 & 1.0935 \\
\hline ROU & 0.65 & 4.7828 & 3.8386 & 0.0311 & 0.0249 & 1.2460 \\
\hline EST & 0.65 & 5.8228 & 3.8206 & 0.0380 & 0.0249 & 1.5241 \\
\hline LVA & 0.68 & 4.3396 & 3.6439 & 0.0297 & 0.0249 & 1.1909 \\
\hline SVK & 0.74 & 7.1852 & 3.3900 & 0.0528 & 0.0249 & 2.1195 \\
\hline PRT & 0.79 & 4.2475 & 3.1379 & 0.0337 & 0.0249 & 1.3536 \\
\hline HUN & 0.95 & 6.1798 & 2.6352 & 0.0585 & 0.0249 & 2.3451 \\
\hline CZE & 1.23 & 4.9969 & 2.0171 & 0.0617 & 0.0249 & 2.4773 \\
\hline ESP & 1.45 & 2.3547 & 1.7142 & 0.0342 & 0.0249 & 1.3736 \\
\hline ITA & 1.59 & 2.4878 & 1.5605 & 0.0396 & 0.0249 & 1.5942 \\
\hline IRL & 1.83 & 8.5415 & 1.3578 & 0.1566 & 0.0249 & 6.2906 \\
\hline SVN & 2.10 & 2.6433 & 1.1892 & 0.0554 & 0.0249 & 2.2226 \\
\hline AUS & 2.63 & 2.5428 & 0.9438 & 0.0669 & 0.0248 & 2.6943 \\
\hline LUX & 2.78 & 2.7089 & 0.8977 & 0.0752 & 0.0249 & 3.0178 \\
\hline NLD & 3.10 & 2.6264 & 0.7984 & 0.0813 & 0.0247 & 3.2896 \\
\hline GBR & 3.36 & 1.4377 & 0.7376 & 0.0482 & 0.0247 & 1.9492 \\
\hline CAN & 3.36 & 6.5655 & 0.7276 & 0.2208 & 0.0245 & 9.0230 \\
\hline BEL & 3.62 & 2.9878 & 0.6830 & 0.1081 & 0.0247 & 4.3743 \\
\hline AUT & 4.34 & 2.0996 & 0.5698 & 0.0910 & 0.0247 & 3.6847 \\
\hline FRA & 4.36 & 1.1977 & 0.5639 & 0.0522 & 0.0246 & 2.1240 \\
\hline DNK & 4.88 & 1.7929 & 0.5072 & 0.0876 & 0.0248 & 3.5350 \\
\hline DEU & 5.41 & 1.5765 & 0.4419 & 0.0853 & 0.0239 & 3.5675 \\
\hline USA & 5.70 & 0.6001 & 0.4182 & 0.0342 & 0.0238 & 1.4348 \\
\hline FIN & 6.11 & 1.6203 & 0.4055 & 0.0989 & 0.0248 & 3.9956 \\
\hline JPN & 7.70 & 0.5607 & 0.3144 & 0.0432 & 0.0242 & 1.7834 \\
\hline SWE & 8.15 & 1.4851 & 0.3016 & 0.1210 & 0.0246 & 4.9235 \\
\hline \multicolumn{7}{|c|}{ Average: } \\
\hline \multirow{2}{*}{\multicolumn{2}{|c|}{$\begin{array}{r}\text { low } R \& D / X \text { countries } \\
\text { high } R \& D / X \text { countries }\end{array}$}} & 7.8202 & 5.7554 & 0.0382 & 0.0249 & 1.5320 \\
\hline & & 2.5617 & 0.6786 & 0.0891 & 0.0246 & 3.6194 \\
\hline
\end{tabular}


The ratio of the MSR to MPR is larger for the R\&D intensive group. The average ratio of the MSR to MPR is 3.62 for the $R \& D$ intensive group, while it is 1.53 for the less R\&D intensive group. We can also confirm this larger gap between the MSR and MPR for the R\&D intensive countries in terms of elasticity. The social returns in terms of elasticity is on average 0.089 for the $R \& D$ intensive countries and 0.038 for less $R \& D$ intensive countries. There is no discernible difference of the private returns in terms of elasticity between $R \& D$ intensive group and less $R \& D$ intensive group. It centers on $0.024 .^{15}$

We obtain two main findings in this section. First, the MSR exceeds the MPR in 'all sectors' and business sector for R\&D intensive countries. Second, R\&D intensive countries have a larger gap between the MSR and the MPR. It implies that R\&D intensive countries are expected to generate more spillovers at the margin, but the observed R\&D is smaller than the socially optimal level.

\section{Concluding Remarks}

We examine empirically the extent to which technology is spread across countries by way of import flows. We find that international technology spillovers play an important role in enhancing productivity. Attention has been paid to the R\&D stock of business sector in the previous studies, but one of our contributions to the literature is construction of the synthetic $\mathrm{R} \& \mathrm{D}$ stock composed of business, government and education stocks by principal component analysis. Our evidence indicates the R\&D stocks of government and education sectors as well as business sector have contributed to economic growth of foreign countries. Furthermore, our estimates of the marginal social returns on $R \& D$ stock are much higher than the marginal private returns for $R \& D$ intensive countries. This implies underinvestment in $R \& D$ activities for $R \& D$ intensive countries from a social point of view. Policy measures, such as R\&D investment credits and subsidies, are needed to induce R\&D investment in the business sector. However, $R \& D$ externalities deprive recipient countries of $R \& D$ spillovers of incentives to invest

${ }^{15}$ For robustness check, we also compute the MSR and MPR of business sector, based on the coefficient estimates of domestic and foreign stock of the business sector in R\&D investment function where the business $R \& D$ stock is used instead of the synthetic R\&D stock (Table 7). We use the same coefficient estimates of the TFP function. The obtained MPR remains almost intact and the MSR has somewhat larger variations. In particular the MSR of Canada and Ireland is -88.724 and 86.561 , respectively. It reflects very small changes in the R\&D stock (denominator of the MSR) resulting from both positive changes in own R\&D stock and negative changes in R\&D stock in U.S. of about the same order. When we compute the correlation coefficient of the MPR of business sector between the two cases, it is 0.99 for MPR and 0.99 for MSR when Canada and Ireland are excluded. 
in $\mathrm{R} \& \mathrm{D}$ activities. Therefore, we should devise international coordination to curb 'prisoner's dilemma' situation and activate R\&D investment.

It is also important to devise effective policy measures to increase $R \& D$ investment in basic research and education by the public sector. $R \& D$ investment in these fields has wide externalities across countries. Therefore some rules to share the costs of implementing public R\&D investment should be discussed and agreed upon internationally.

Last but not least, it is also an important avenue for future research to investigate quantitatively the role of $R \& D$ spillovers in the process of productivity convergence, which was seen in Figure 2. 


\section{References}

Acharta, R. C. and W. Keller (2008). "Estimating the Productivity Selection and Technology Spillover Effects of Imports,” NBER Working Paper No. 14079.

Adams, J. (1990). "Fundamental Stocks of Knowledge and Productivity Growth," Journal of Political Economy Vol. 98, pp. 673-702.

Aitken, B. ad A. Harrison (1999). "Do Domestic Firms Benefit from Foreign Direct Investment? Evidence from Venezuela," American Economic Review Vol. 89, No. 3, pp. 605-618.

Ark, B. van, V. Chen, B. Colijn, K. Jaeger, W. Overmeer and M.P. Timmer (2013), "Recent Changes in Europe's Competitive Landscape and Medium-Term Perspectives: How the Sources of Demand and Supply are Shaping Up", European Economy, Economic Papers, 485.

Blalock, G. and P. Gertler (2002). "Welfare Gains from Foreign Direct Investment through Technology Transfer to Local Suppliers," Journal of International Economics Vol. 74, No. 2, pp. 402-421.

Bloom, N., M. Schankerman and J.V. Reenen (2013). "Identifying Technology Spillovers and Product Market Rivalry,” Econometrica Vol.81, No.4, pp.1347-1393.

Branstetter, L. (2001). "Is Foreign Direct Investment a Channel of Knowledge Spillovers? Evidence from Japan's FDI in the United States," NBER Working Paper No. 8015 .

Coe, D. and E. Helpman (1995). "International R\&D Spillovers," European Economic Review Vol. 39, No. 5, pp. 859-887.

Coe, D., E. Helpman and A. Hoffmaister (1997). "North-South Spillovers," Economic Journal Vol. 107, pp. 134-149.

Coe, D. and A. Hoffmaister (1999). "Are There International R\&D Spillovers among Randomly Matched Trade Partners? A Response to Keller," IMF working paper 99/18.

Coe, D., E. Helpman and A. Hoffmaister (2008). "International R\&D Spillovers and Institutions," NBER Working Paper No. 14069.

Eaton, J. and S. Kortum (1999). "International Patenting and Technology Diffusion: 
Theory and Measurement," International Economic Review Vol. 40, pp. 537-570.

Funk, M. (2001). “Trade and International R\&D Spillovers among OECD Countries," Southern Economic Journal Vol. 3, pp. 725-736.

Globerman, S., A. Kokko and F. Sjöholm (2000). "International Technology Diffusion: Evidence from Swedish Patent Data," Kyklos Vol. 53, pp. 17-38.

Griliches, Z. (1992). "The Search for R\&D Spillovers," Scandinavian Journal of Economics Vol. 94, pp. 29-47.

Guellec, D. and B. van Pottelsberghe de la Potterie (2004). "From R\&D to Productivity Growth: Do the Institutional Settings and the Source of Funds of R\&D Matter?" Oxford Bulletin of Economics and Statistics Vol. 66, No. 3, pp. 353-378.

Haskel, J., S. Pereira and M. Slaughter (2002). "Does Inward Foreign Direct Investment Boost the Productivity of Domestic Firms?” NBER Working Paper No. 8724.

Jaffe, A. B. (1986). "Technology Opportunity and Spillovers of R\&D: Evidence from Firms' Patents, Profits, and Market Value,” American Economic Review Vol. 76, pp. 984-1001.

Javorcik, B. (2004), "Does Foreign Direct Investment Increase the Productivity of Domestic Firms? In Search of Spillovers through Backward Linkages," American Economic Review Vol. 94, No. 3, pp. 605-627.

Javorcik, B., and M. Spatareanu (2008), "To Share or not to Share: Does Local Participation Matter for Spillovers from Foreign Direct Investment?" Journal of Development Economics Vol. 85, pp. 194-217.

Keller, W. (1998). "Are International R\&D Spillovers Trade Related? Analyzing Spillovers among Randomly Matched Trade Partners," European Economic Review Vol. 42, pp. 1469-1481.

Keller,W. (2002). "Geographic Localization of International Technology Diffusion," American Economic Review Vol. 92, pp. 120-142.

Keller,W. (2004). "International Technology Diffusion," Journal of Economic Literature Vol. 42, pp. 752-782.

Keller, W. (2009).” International Trade, Foreign Direct Investment, and Technology Spillovers," NBER Working Paper No. 15442. 
Keller, W., and S. Yeaple (2009), "Multinational Enterprises, International Trade, and Productivity Growth: Firm-level Evidence from the United States," Review of Economics and Statistics Vol. 91, No. 4, pp. 821-831.

Lee, G. (2006). "The Effectiveness of International Knowledge Spillover Channels," European Economic Review Vol. 50, pp. 2075 - 2088.

Lichtenberg, F. and B. Van Pottelsberghe de la Potterie (1998). "International R\&D Spillovers: A Comment," European Economic Review Vol.42, pp. 1483-1491.

Lumenga-Neso, O., M. Olarreaga and M. Schiff (2005). "On 'Indirect' Trade-Related R\&D Spillovers,” European Economic Review, Vol.49, pp. 1785-1797.

Madsen, J. B. (2007). "Technology Spillover through Trade and TFP Convergence: 135 years of Evidence for the OECD Countries," Journal of International Economics Vol. 72, pp. 464-480.

Nadiri, M.I. and T.P. Mamuneas (1994). "Effects of Public Infrastructures and R\&D Capital on the Cost Structure and Performance of US Manufacturing Industries," Review of Economics and Statistics Vol.76, No. 1, pp. 22-37.

Park, W. G. (1995). "International R\&D Spillovers and OECD Economic Growth," Economic Inquiry Vol. 23, pp. 571-591.

Saito, M. and I. Tokutsu (2015), "Revisiting the 'Great Trade Collapse' with the Endogenous Input-Choice Model,” Oxford Economic Papers Vol. 67, pp. 1123-1145.

Seck, A. (2012). "International Technology Diffusion and Economic Growth: Explaining the Spillover Benefits to Developing Countries," Structural Change and Economic Dynamics Vol. 23, pp. 437-451.

Sjöholm, F. (1996). "International Transfer of Knowledge: The Role of International Trade and Geographic Proximity," Weltwirtschaftliches Archiv Vol.132, pp. 97-115.

Stiglitz. J.E. (2012), The Price of Inequality, W. W. Norton.

Van Pottelsberghe de la Potterie, B. and F.R. Lichtenberg (2001). "Does Foreign Direct Investment Transfer Technology across Borders?" Review of Economics and Statistics Vol. 83, No. 3, pp. 490-497.

Xu, B., and J. Wang (1999). "Capital Goods Trade and R\&D Spillovers in the OECD," Canadian Journal of Economics Vol. 32, pp. 1258-1274. 
Verspagen, B. (1997). "Estimating International Technology Spillovers Using Technology Flow Matrices," Weltwirtschaftliches Archiv, Band 133, Heft 2, pp. 226-248.

Xu, B. (2000). "Multinational Enterprises, Technology Diffusion, and Host Country Productivity Growth," Journal of Development Economics Vol. 62, No. 2, pp. 477-93.

Zhu, L. and B. Jeon (2007). "International R\&D Spillovers: Trade, FDI, and Information Technology as Spillover Channels," Review of International Economics Vol. 15, No. 5, pp. 955-976. 
Appendix A: Log-linear Approximation of $\ln \left(\sum_{j \neq i} \alpha_{i j} S_{j}^{d}\right)$

$$
\begin{aligned}
& \ln \left(\sum_{j \neq i} \alpha_{i j} S_{j}^{d}\right)=\ln \left(\sum_{j \neq i} \alpha_{i j} e^{\ln S_{j}^{d}}\right) \cong \ln \left(\sum_{j \neq i} \alpha_{i j} e^{\ln S_{j}^{d 0}}\right) \\
& +\sum_{j \neq i}\left(\frac{\alpha_{i j} e^{\ln S_{j}^{d 0}}}{\sum_{j \neq i} \alpha_{i j} e^{\ln S_{j}^{d 0}}}\right) \times\left(\ln S_{j}^{d}-\ln S_{j}^{d 0}\right) \\
& =\left\{\ln \left(\sum_{j \neq i} \alpha_{i j} S_{j}^{d 0}\right)-\sum_{j \neq i}\left(\frac{\alpha_{i j} S_{j}^{d 0}}{\sum_{j \neq i} \alpha_{i j} S_{j}^{d 0}}\right) \ln S_{j}^{d 0}\right\} \\
& +\sum_{j \neq i}\left(\frac{\alpha_{i j} S_{j}^{d 0}}{\sum_{j \neq i} \alpha_{i j} S_{j}^{d 0}}\right) \ln S_{j}^{d}=\lambda_{i}+\sum_{j \neq i} \theta_{i j} \ln S_{j}^{d}
\end{aligned}
$$

where

$$
\begin{gathered}
\theta_{i j}=\frac{\alpha_{i j} S_{j}^{d 0}}{\sum_{j \neq i} \alpha_{i j} S_{j}^{d 0}} \text { and } \\
\lambda_{i}=\ln \left(\sum_{j \neq i} \alpha_{i j} S_{j}^{d 0}\right)-\sum_{j \neq i}\left(\frac{\alpha_{i j} S_{j}^{d 0}}{\sum_{j \neq i} \alpha_{i j} S_{j}^{d 0}}\right) \ln S_{j}^{d 0} .
\end{gathered}
$$




\section{Appendix B: Construction of Domestic R\&D Stock}

In this appendix we explain the procedure to construct domestic R\&D stock. The basic data come from the EuroStat. EuroStat provides the time series of nominal R\&D expenditure in local currency for business sector, government sector, high-education sector and non-profit sector as well as for all sectors, i.e. economy as a whole.

Nominal R\&D expenditures are converted to real R\&D expenditures by GDP deflator $(1995=1.00)$ and further converted to 1995 US constant dollar by the exchange rates of the corresponding countries in $1995 .{ }^{16}$ GDP deflators and the exchange rates are taken from the Socio Economic Account of WIOD.

The real R\&D capital stocks (in 1995 US constant dollar) are calculated using the perpetual inventory method as

$$
S_{i, t}^{d}=R_{i, t}^{d}+(1-\delta) S_{i, t-1}^{d},
$$

where $S_{i, t}^{d}$ is the real domestic R\&D capital stock of country $i$ at the end of period $t$, $R_{i, t}^{d}$ is the real domestic $\mathrm{R} \& \mathrm{D}$ expenditure of country $i$ in period $t$ and $\delta$ is the depreciation rate of real $R \& D$ stock assumed to be 0.15 .

The initial real $R \& D$ capital stock is obtained by

$$
S_{i, 0}^{d}=R_{i, 1}^{d} /\left(\delta+g_{i}\right),
$$

where $g_{i}$ is the average growth rate of real R\&D expenditure in the sample period,

$$
g_{i}=\left(\ln R_{i, T}^{d}-\ln R_{i, 1}^{d}\right) /(T-1) .
$$

For the initial $R \& D$ capital stock in equation (A-2), we apply the growth rate of all sectors in common to each sector to satisfy the adding up constraints on real R\&D capital stock. For example, we apply the average growth rate of all sectors, $5.56 \%$, to business sector, government sector and education sector as well as all sectors of Australia; otherwise the total sum of business sector, government sector and education sector sometimes exceeds the R\&D capital stock of all sectors.

We calculated the real R\&D expenditures and capital stocks by sectors; business sector, government sector and education sector as well as for the economy as a whole. The average growth rates of $\mathrm{R} \& \mathrm{D}$ expenditures and capital stocks are presented by sector in Table A2.

${ }^{16}$ In EuroStat R\&D expenditure are missing for some countries and sectors. In such cases we estimate them in principle by linear interpolation as far as they have the data at both ends. We do not extrapolate the data when they are truncated and thus the sample period is shorter for some countries. See note to Table A2 for individual case. 
Appendix C: Computation of marginal social returns and private returns on R\&D when the R\&D stock is constructed by principal component analysis

In this Appendix we explain the procedure to compute marginal social returns and private returns on $R \& D$ stock when we use the synthetic $R \& D$ stock constructed by principal component analysis.

We assume that there are $N$ countries across which technology is spread by way of $R \& D$ stocks. The production function is a Cobb-Douglas type where the gross output is produced by labor, intermediate inputs, capital stock and domestic and foreign synthetic R\&D stocks.

\section{C1. Production Function}

The production function is written as

$$
\begin{aligned}
\ln X_{i}= & \varphi_{0}+\varphi_{K} \ln K_{i}+\varphi_{L} \ln L_{i}+\varphi_{I M} \ln I M_{i}+\varphi_{1} Z_{i}^{d} \\
& +\varphi_{2} Z_{i}^{f}, \quad(i=1, \cdots, N)
\end{aligned}
$$

where $X_{i}$ : gross output of country $i$,

$K_{i}$ : capital stock of country $i$,

$L_{i}$ : labor input of country $i$,

$I M_{i}$ : intermediate input of country $i$,

$Z_{i}^{d}$ : principal component of domestic R\&D stock of country $i$ and

$Z_{i}^{f}$ : principal component of foreign R\&D stock of country $i$.

The principal component of domestic R\&D stock of country $i$ is a linear combination of the logarithm of R\&D stock in business sector, government sector and education sector or

$$
Z_{i}^{d}=\omega_{d B} \ln S_{i}^{d B}+\omega_{d G} \ln S_{i}^{d G}+\omega_{d E} \ln S_{i}^{d E},
$$

where $S_{i}^{d B}:$ R\&D stock in the business sector of country $i$,

$S_{i}^{d G}: \mathrm{R} \& \mathrm{D}$ stock in the government sector of country $i$ and

$S_{i}^{d E}: \mathrm{R} \& \mathrm{D}$ stock in the education sector of country $i$.

In a similar way the principal component of foreign R\&D stock of country $i$ is a linear combination of the logarithm of foreign R\&D stock in business sector, government sector and education sector of country $i$ or

$$
Z_{i}^{f}=\omega_{f B} \ln S_{i}^{f B}+\omega_{f G} \ln S_{i}^{f G}+\omega_{f E} \ln S_{i}^{f E},
$$


where $S_{i}^{f B}$ : foreign R\&D stock in the business sector of country $i$,

$S_{i}^{f G}$ : foreign R\&D stock in the government sector of country $i$ and

$S_{i}^{f E}$ : foreign R\&D stock in the education sector of country $i$.

Substituting eqs. (A-5) and (A-6) into eq.(A-4), we obtain

$$
\begin{aligned}
\ln X_{i}= & \varphi_{0}+\varphi_{K} \ln K_{i}+\varphi_{L} \ln L_{i}+\varphi_{I M} \ln I M_{i} \\
& +\varphi_{1}\left(\omega_{d B} \ln S_{i}^{d B}+\omega_{d G} \ln S_{i}^{d G}+\omega_{d E} \ln S_{i}^{d E}\right) \\
& +\varphi_{2}\left(\omega_{f B} \ln S_{i}^{f B}+\omega_{f G} \ln S_{i}^{f G}+\omega_{f E} \ln S_{i}^{f E}\right)
\end{aligned}
$$

The foreign R\&D stock is a linear combination of each country's R\&D stock as,

$$
\begin{aligned}
& \ln S_{i}^{f B}=\ln \left(\sum_{j \neq i} \alpha_{i j}^{B} S_{j}^{d B}\right), \\
& \ln S_{i}^{f G}=\ln \left(\sum_{j \neq i} \alpha_{i j}^{G} S_{j}^{d G}\right), \\
& \ln S_{i}^{f E}=\ln \left(\sum_{j \neq i} \alpha_{i j}^{E} S_{j}^{d E}\right) .
\end{aligned}
$$

As was shown in Appendix A, the logarithm of foreign R\&D stock is approximately written as a linear combination of each country's logarithmic domestic R\&D stocks. In other words,

$$
\begin{aligned}
& \ln \left(\sum_{j \neq i} \alpha_{i j}^{B} S_{i}^{d B}\right)=\lambda_{i}^{B}+\sum_{j \neq i} \theta_{i j}^{B} \ln S_{j}^{d B}, \\
& \ln \left(\sum_{j \neq i} \alpha_{i j}^{G} S_{i}^{d G}\right)=\lambda_{i}^{G}+\sum_{j \neq i} \theta_{i j}^{G} \ln S_{j}^{d G}, \\
& \ln \left(\sum_{j \neq i} \alpha_{i j}^{E} S_{i}^{d E}\right)=\lambda_{i}^{E}+\sum_{j \neq i} \theta_{i j}^{E} \ln S_{j}^{d E} .
\end{aligned}
$$

Substituting eqs. (A-8) to (A-10) into eq. (A-7), we obtain

$$
\begin{aligned}
\ln X_{i}=\left(\varphi_{0}+\right. & \left.\varphi_{2} \omega_{f B} \lambda_{i}^{B}+\varphi_{2} \omega_{f G} \lambda_{i}^{G}+\varphi_{2} \omega_{f e} \lambda_{i}^{e}\right)+\varphi_{K} \ln K_{i} \\
& +\varphi_{L} \ln L_{i}+\varphi_{M} \ln I M_{i} \\
& +\left(\varphi_{1} \omega_{d B} \ln S_{i}^{d B}+\varphi_{2} \omega_{f B} \sum_{j \neq i} \theta_{i j}^{B} \ln S_{j}^{d B}\right) \\
& +\left(\varphi_{1} \omega_{d G} \ln S_{i}^{d G}+\varphi_{2} \omega_{f G} \sum_{j \neq i} \theta_{i j}^{G} \ln S_{j}^{d G}\right)
\end{aligned}
$$




$$
+\left(\varphi_{1} \omega_{d E} \ln S_{i}^{d E}+\varphi_{2} \omega_{f E} \sum_{j \neq i} \theta_{i j}^{E} \ln S_{j}^{d E}\right)
$$

In matrix notation,

$$
\begin{aligned}
\ln \mathbf{x}=\varphi_{\mathbf{0}}+ & \boldsymbol{\varphi}_{K} \ln \mathbf{k}+\boldsymbol{\varphi}_{L} \ln \mathbf{l}+\boldsymbol{\varphi}_{M} \ln \mathbf{i m}+\boldsymbol{\Phi}^{B} \ln \mathbf{s}^{B}+\boldsymbol{\Phi}^{G} \ln \mathbf{s}^{B} \\
& +\boldsymbol{\Phi}^{E} \ln \mathbf{s}^{E}
\end{aligned}
$$

where

$$
\begin{aligned}
& \ln \mathbf{x}=\left[\begin{array}{c}
\ln X_{1} \\
\ln X_{2} \\
\vdots \\
\ln X_{N}
\end{array}\right], \ln \mathbf{k}=\left[\begin{array}{c}
\ln K_{1} \\
\ln K_{2} \\
\vdots \\
\ln K_{N}
\end{array}\right], \ln \mathbf{l}=\left[\begin{array}{c}
\ln L_{1} \\
\ln L_{2} \\
\vdots \\
\ln L_{N}
\end{array}\right], \ln \mathbf{i m}=\left[\begin{array}{c}
\ln I M_{1} \\
\ln I M_{2} \\
\vdots \\
\ln I M_{N}
\end{array}\right], \\
& \ln \mathbf{s}^{B}=\left[\begin{array}{c}
\ln S_{1}^{d B} \\
\ln S_{2}^{d B} \\
\vdots \\
\ln S_{N}^{d B}
\end{array}\right], \ln \mathbf{s}^{G}=\left[\begin{array}{c}
\ln S_{1}^{d G} \\
\ln S_{2}^{d G} \\
\vdots \\
\ln S_{N}^{d G}
\end{array}\right], \ln \mathbf{s}^{E}=\left[\begin{array}{c}
\ln S_{1}^{d E} \\
\ln S_{2}^{d E} \\
\vdots \\
\ln S_{N}^{d E}
\end{array}\right] \\
& \boldsymbol{\varphi}_{\mathbf{0}}=\left[\begin{array}{c}
\varphi_{0}+\varphi_{2} \omega_{f B} \lambda_{1}^{B}+\varphi_{2} \omega_{f G} \lambda_{1}^{G}+\varphi_{2} \omega_{f E} \lambda_{1}^{E} \\
\varphi_{0}+\varphi_{2} \omega_{f B} \lambda_{2}^{B}+\varphi_{2} \omega_{f G} \lambda_{2}^{G}+\varphi_{2} \omega_{f E} \lambda_{2}^{E} \\
\vdots \\
\varphi_{0}+\varphi_{2} \omega_{f B} \lambda_{N}^{B}+\varphi_{2} \omega_{f G} \lambda_{N}^{G}+\varphi_{2} \omega_{f E} \lambda_{N}^{E}
\end{array}\right] \\
& \boldsymbol{\Phi}^{B}=\left[\begin{array}{cccc}
\varphi_{1} \omega_{d B} & \varphi_{2} \omega_{f B} \theta_{12}^{B} & \cdots & \varphi_{2} \omega_{f B} \theta_{1 N}^{B} \\
\varphi_{2} \omega_{f B} \theta_{21}^{B} & \varphi_{1} \omega_{d B} & \cdots & \varphi_{2} \omega_{f B} \theta_{2 N}^{B} \\
\vdots & \vdots & \ddots & \vdots \\
\varphi_{2} \omega_{f B} \theta_{N 1}^{B} & \varphi_{2} \omega_{f B} \theta_{N 2}^{B} & \cdots & \varphi_{1} \omega_{d B}
\end{array}\right] \text {, } \\
& \boldsymbol{\Phi}^{G}=\left[\begin{array}{cccc}
\varphi_{1} \omega_{d G} & \varphi_{2} \omega_{f G} \theta_{12}^{G} & \cdots & \varphi_{2} \omega_{f G} \theta_{1 N}^{G} \\
\varphi_{2} \omega_{f G} \theta_{21}^{G} & \varphi_{1} \omega_{d G} & \cdots & \varphi_{2} \omega_{f G} \theta_{2 N}^{G} \\
\vdots & \vdots & \ddots & \vdots \\
\varphi_{2} \omega_{f G} \theta_{N 1}^{G} & \varphi_{2} \omega_{f G} \theta_{N 2}^{G} & \cdots & \varphi_{1} \omega_{d G}
\end{array}\right] \text {, }
\end{aligned}
$$




$$
\boldsymbol{\Phi}^{E}=\left[\begin{array}{cccc}
\varphi_{1} \omega_{d E} & \varphi_{2} \omega_{f E} \theta_{12}^{E} & \cdots & \varphi_{2} \omega_{f E} \theta_{1 N}^{E} \\
\varphi_{2} \omega_{f E} \theta_{21}^{E} & \varphi_{1} \omega_{d E} & \cdots & \varphi_{2} \omega_{f E} \theta_{2 N}^{E} \\
\vdots & \vdots & \ddots & \vdots \\
\varphi_{2} \omega_{f E} \theta_{N 1}^{E} & \varphi_{2} \omega_{f E} \theta_{N 2}^{E} & \cdots & \varphi_{1} \omega_{d E}
\end{array}\right] .
$$

\section{C2. R\&D Investment Function}

$\mathrm{R} \& \mathrm{D}$ investment function of the business sector is specified as a function of domestic and foreign synthetic R\&D stocks, output growth rate, and debt outstanding or

$$
\ln R_{i}^{B}=\mu_{0}+\mu_{1} Z_{i}^{d}+\mu_{2} Z_{i}^{f}+\mu_{3} \Delta \ln X_{i}+\mu_{4} \ln D_{i}^{B},(i=1,2, \cdots, N),
$$

where $R_{i}^{B}: \mathrm{R} \& \mathrm{D}$ investment in the business sector of country $i$ and

$D_{i}^{B}$ : Debt outstanding in the business sector of country $i$.

Substituting eqs. (A-5) and (A-6) into eq. (A-13),

$$
\begin{aligned}
\ln R_{i}^{B}= & \mu_{0}+\mu_{1}\left(\omega_{d B} \ln S_{i}^{d B}+\omega_{d G} \ln S_{i}^{d G}+\omega_{d E} \ln S_{i}^{d E}\right) \\
& +\mu_{2}\left(\omega_{f B} \ln S_{i}^{f B}+\omega_{f G} \ln S_{i}^{f G}+\omega_{f E} \ln S_{i}^{f E}\right) \\
& +\mu_{3} \Delta \ln X_{i}+\mu_{4} \ln D_{i}^{B} .
\end{aligned}
$$

Substitution of eqs. (A-8) to (A-10) into eq. (A-14) further simplifies eq. (A-14) as

$$
\begin{aligned}
\ln R_{i}^{B}=( & \left.\mu_{0}+\mu_{2} \omega_{f B} \lambda_{i}^{B}+\mu_{2} \omega_{f G} \lambda_{i}^{G}+\mu_{2} \omega_{f E} \lambda_{i}^{E}\right)+\mu_{3} \Delta \ln X_{i} \\
& +\mu_{4} \ln D_{i}^{B}+\left(\mu_{1} \omega_{d B} \ln S_{i}^{d B}+\mu_{2} \omega_{f B} \sum_{j \neq i} \theta_{i j}^{B} \ln S_{j}^{d B}\right) \\
& +\left(\mu_{1} \omega_{d G} \ln S_{i}^{d G}+\mu_{2} \omega_{f G} \sum_{j \neq i} \theta_{i j}^{G} \ln S_{j}^{d G}\right) \\
& +\left(\mu_{1} \omega_{d E} \ln S_{i}^{d E}+\mu_{2} \omega_{f E} \sum_{j \neq i} \theta_{i j}^{E} \ln S_{j}^{d E}\right)
\end{aligned}
$$

In steady state, the following equality is held between $R \& D$ investment and $R \& D$ stock:

$$
S_{i}^{B}=R_{i}^{B} / \delta \text { or } \ln S_{i}^{B}=\ln R_{i}^{B}-\ln \delta .
$$

Moreover, in steady state the growth rate of $X_{i}$ is constant, say $g_{i}$

$$
\Delta \ln X_{i}=g_{i}
$$

Substituting eqs. (A-16) and (A-17) into eq. (A-15), we obtain 


$$
\begin{aligned}
\ln S_{i}^{B}=\left(\mu_{0}\right. & \left.+\mu_{2} \omega_{f B} \lambda_{i}^{B}+\mu_{2} \omega_{f G} \lambda_{i}^{G}+\mu_{2} \omega_{f E} \lambda_{i}^{E}-\ln \delta+\mu_{3} g_{i}\right) \\
& +\mu_{4} \ln D_{i}^{B}+\left(\mu_{1} \omega_{d B} \ln S_{i}^{B}+\mu_{2} \omega_{f B} \sum_{j \neq i} \theta_{i j}^{B} \ln S_{j}^{B}\right) \\
& +\left(\mu_{1} \omega_{d G} \ln S_{i}^{G}+\mu_{2} \omega_{f G} \sum_{j \neq i} \theta_{i j}^{G} \ln S_{j}^{G}\right) \\
& +\left(\mu_{1} \omega_{d E} \ln S_{i}^{E}+\mu_{2} \omega_{f E} \sum_{j \neq i} \theta_{i j}^{E} \ln S_{j}^{E}\right)
\end{aligned}
$$

In matrix notation,

$$
\ln \mathbf{s}^{B}=\zeta_{\mathbf{0}}+\boldsymbol{\Psi}^{B} \ln \mathbf{s}^{B}+\boldsymbol{\Psi}^{G} \ln \mathbf{s}^{G}+\boldsymbol{\Psi}^{E} \ln \mathbf{s}^{E}+\mu_{4} \ln \mathbf{d}^{B},
$$

where

$$
\begin{aligned}
& \zeta_{0}=\left[\begin{array}{c}
\mu_{0}+\mu_{2} \omega_{f B} \lambda_{1}^{B}+\mu_{2} \omega_{f G} \lambda_{1}^{G}+\mu_{2} \omega_{f E} \lambda_{1}^{E}-\ln \delta+\mu_{3} g_{1} \\
\mu_{0}+\mu_{2} \omega_{f B} \lambda_{2}^{B}+\mu_{2} \omega_{f G} \lambda_{2}^{G}+\mu_{2} \omega_{f E} \lambda_{2}^{E}-\ln \delta+\mu_{3} g_{2} \\
\vdots \\
\mu_{0}+\mu_{2} \omega_{f B} \lambda_{N}^{B}+\mu_{2} \omega_{f G} \lambda_{N}^{G}+\mu_{2} \omega_{f E} \lambda_{N}^{E}-\ln \delta+\mu_{3} g_{N}
\end{array}\right], \\
& \boldsymbol{\Psi}^{B}=\left[\begin{array}{cccc}
\mu_{1} \omega_{d B} & \mu_{2} \omega_{f B} \theta_{12}^{B} & \cdots & \mu_{2} \omega_{f B} \theta_{1 N}^{B} \\
\mu_{2} \omega_{f B} \theta_{21}^{B} & \mu_{1} \omega_{d B} & \cdots & \mu_{2} \omega_{f B} \theta_{2 N}^{B} \\
\vdots & \vdots & \ddots & \vdots \\
\mu_{2} \omega_{f B} \theta_{N 1}^{B} & \mu_{2} \omega_{f B} \theta_{N 2}^{B} & \cdots & \mu_{1} \omega_{d B}
\end{array}\right] \\
& \boldsymbol{\Psi}^{G}=\left[\begin{array}{cccc}
\mu_{1} \omega_{d G} & \mu_{2} \omega_{f G} \theta_{12}^{G} & \cdots & \mu_{2} \omega_{f G} \theta_{1 N}^{G} \\
\mu_{2} \omega_{f G} \theta_{21}^{G} & \mu_{1} \omega_{d G} & \cdots & \mu_{2} \omega_{f G} \theta_{2 N}^{G} \\
\vdots & \vdots & \ddots & \vdots \\
\mu_{2} \omega_{f G} \theta_{N 1}^{G} & \mu_{2} \omega_{f G} \theta_{N 2}^{G} & \cdots & \mu_{1} \omega_{d G}
\end{array}\right], \\
& \boldsymbol{\Psi}^{E}=\left[\begin{array}{cccc}
\mu_{1} \omega_{d E} & \mu_{2} \omega_{f E} \theta_{12}^{E} & \cdots & \mu_{2} \omega_{f E} \theta_{1 N}^{E} \\
\mu_{2} \omega_{f E} \theta_{21}^{E} & \mu_{1} \omega_{d E} & \cdots & \mu_{2} \omega_{f E} \theta_{2 N}^{E} \\
\vdots & \vdots & \ddots & \vdots \\
\mu_{2} \omega_{f E} \theta_{N 1}^{E} & \mu_{2} \omega_{f E} \theta_{N 2}^{E} & \cdots & \mu_{1} \omega_{d E}
\end{array}\right] \\
& \ln \mathbf{d}^{B}=\left[\begin{array}{c}
\ln D_{1}^{B} \\
\ln D_{2}^{B} \\
\vdots \\
\ln D_{N}^{B}
\end{array}\right] .
\end{aligned}
$$


A one percent change in the stock of R\&D in the business sector of country $i$ yields the absolute changes in the levels of R\&D stock in the business sector as follows:

$$
\mathrm{d} \mathbf{s}^{B}=\mathbf{B}_{S}\left(\mathbf{I}-\Psi^{B}\right)^{-\mathbf{1}} \mathbf{z}^{*},
$$

where

$$
\mathbf{B}_{S}=\left[\begin{array}{cccc}
S_{1}^{d B} & 0 & \cdots & 0 \\
0 & S_{2}^{d B} & \cdots & 0 \\
\vdots & \vdots & \ddots & \vdots \\
0 & 0 & \cdots & S_{N}^{d B}
\end{array}\right], \mathrm{d} \mathbf{s}^{B}=\left[\begin{array}{c}
\mathrm{d} S_{1}^{d B} \\
\mathrm{~d} S_{2}^{d B} \\
\vdots \\
\mathrm{d} S_{N}^{d B}
\end{array}\right] \text { and }
$$

$\mathbf{z}^{*}:$ an $N \times 1$ vector with one in the $i$-th position and zero elsewhere.

From the production function eq. (A-12), this induces changes in output as

$$
\mathrm{d} \mathbf{x}=\mathbf{B}_{X} \Phi^{B}\left(I-\Psi^{B}\right)^{-1} \mathbf{z}^{*}
$$

where

$$
\mathbf{B}_{X}=\left[\begin{array}{cccc}
X_{1} & 0 & \cdots & 0 \\
0 & X_{2} & \cdots & 0 \\
\vdots & \vdots & \ddots & \vdots \\
0 & 0 & \cdots & X_{N}
\end{array}\right], \mathrm{d} \mathbf{x}=\left[\begin{array}{c}
\mathrm{d} X_{1} \\
\mathrm{~d} X_{2} \\
\vdots \\
\mathrm{d} X_{N}
\end{array}\right]
$$

Marginal social returns (MSR) on R\&D in the business sector of country $i$ are defined as

$$
M S R_{i}=\frac{(\mathrm{d} \mathbf{x})^{\prime} \mathbf{z}}{\left(\mathrm{d} \mathbf{s}^{B}\right)^{\prime} \mathbf{z}}
$$

where $\mathbf{z}$ : an $N \times 1$ vector of ones.

Marginal private returns (MPR) on R\&D in the business sector of country $i$ are defined as

$$
M P R_{i}=\frac{(\mathrm{d} \mathbf{x})^{\prime} \mathbf{z}^{*}}{\left(\mathrm{~d} \mathbf{s}^{B}\right)^{\prime} \mathbf{z}^{*}}
$$




\section{Appendix Tables}

Table A1 Concordance of sample countries

\begin{tabular}{|c|c|c|c|c|c|}
\hline & & $\begin{array}{c}(1) \\
\text { WIOD }\end{array}$ & $\begin{array}{c}\text { (2) } \\
\text { Our study }\end{array}$ & \begin{tabular}{l}
\multicolumn{1}{c}{$(3)$} \\
Coe and \\
Helpman (1995)
\end{tabular} & $\begin{array}{c}(4) \\
\text { Coe et al. }(2008)\end{array}$ \\
\hline 1 & Australia & 0 & 0 & 0 & 0 \\
\hline 2 & Austria & o & o & o & o \\
\hline 3 & Belgium & o & o & o & o \\
\hline 4 & Bulgaria & 0 & - & & \\
\hline 5 & Brazil & o & & & \\
\hline 6 & Canada & o & 0 & o & 0 \\
\hline 7 & China & o & & & \\
\hline 8 & Cyprus & o & - & & \\
\hline 9 & Czech Republic & o & - & & \\
\hline 10 & Germany & o & 0 & o & 0 \\
\hline 11 & Denmark & o & 0 & o & 0 \\
\hline 12 & Spain & o & o & o & o \\
\hline 13 & Estonia & o & - & & \\
\hline 14 & Finland & o & 0 & o & o \\
\hline 15 & France & o & 0 & o & o \\
\hline 16 & United Kingdom & o & 0 & o & o \\
\hline 17 & Greece & o & 0 & o & 0 \\
\hline 18 & Hungary & o & - & & \\
\hline 19 & Iceland & & & & $*$ \\
\hline 20 & Indnesia & o & & & \\
\hline 21 & India & o & & & \\
\hline 22 & Ireland & o & o & 0 & 0 \\
\hline 23 & Israel & & & $*$ & $*$ \\
\hline 24 & Italy & 0 & o & o & 0 \\
\hline 25 & Japan & o & 0 & o & 0 \\
\hline 26 & Korea & o & & & $*$ \\
\hline 27 & Lithuania & o & - & & \\
\hline 28 & Luxembourg & o & - & & \\
\hline 29 & Latvia & 0 & - & & \\
\hline 30 & Mexico & o & & & \\
\hline 31 & Malta & o & - & & \\
\hline 32 & Netherlands & o & 0 & o & 0 \\
\hline 33 & New Zealand & & & $*$ & $*$ \\
\hline 34 & Norway & & & $*$ & $*$ \\
\hline 35 & Poland & 0 & - & & \\
\hline 36 & Portugal & o & 0 & o & o \\
\hline 37 & Romania & 0 & - & & \\
\hline 38 & Russian Federation & o & & & \\
\hline 39 & Slovakia & o & - & & \\
\hline 40 & Slovenia & o & - & & \\
\hline 41 & Sweden & o & 0 & o & 0 \\
\hline 42 & Switzerland & & & $*$ & * \\
\hline 43 & Turkey & o & - & & \\
\hline 44 & Taiwan & 0 & & & \\
\hline \multirow[t]{2}{*}{45} & United States & o & o & o & o \\
\hline & Number of countries & 40 & 32 & 22 & 24 \\
\hline
\end{tabular}

- Countries in our study but not in Coe and Helpman (1995) or Coe et al. (2008).

* Countries in Coe and Helpman (1995) or Coe et al. (2008) but not in our study. 
Table A2: Average growth rate of domestic R\&D: 1995 - 2009

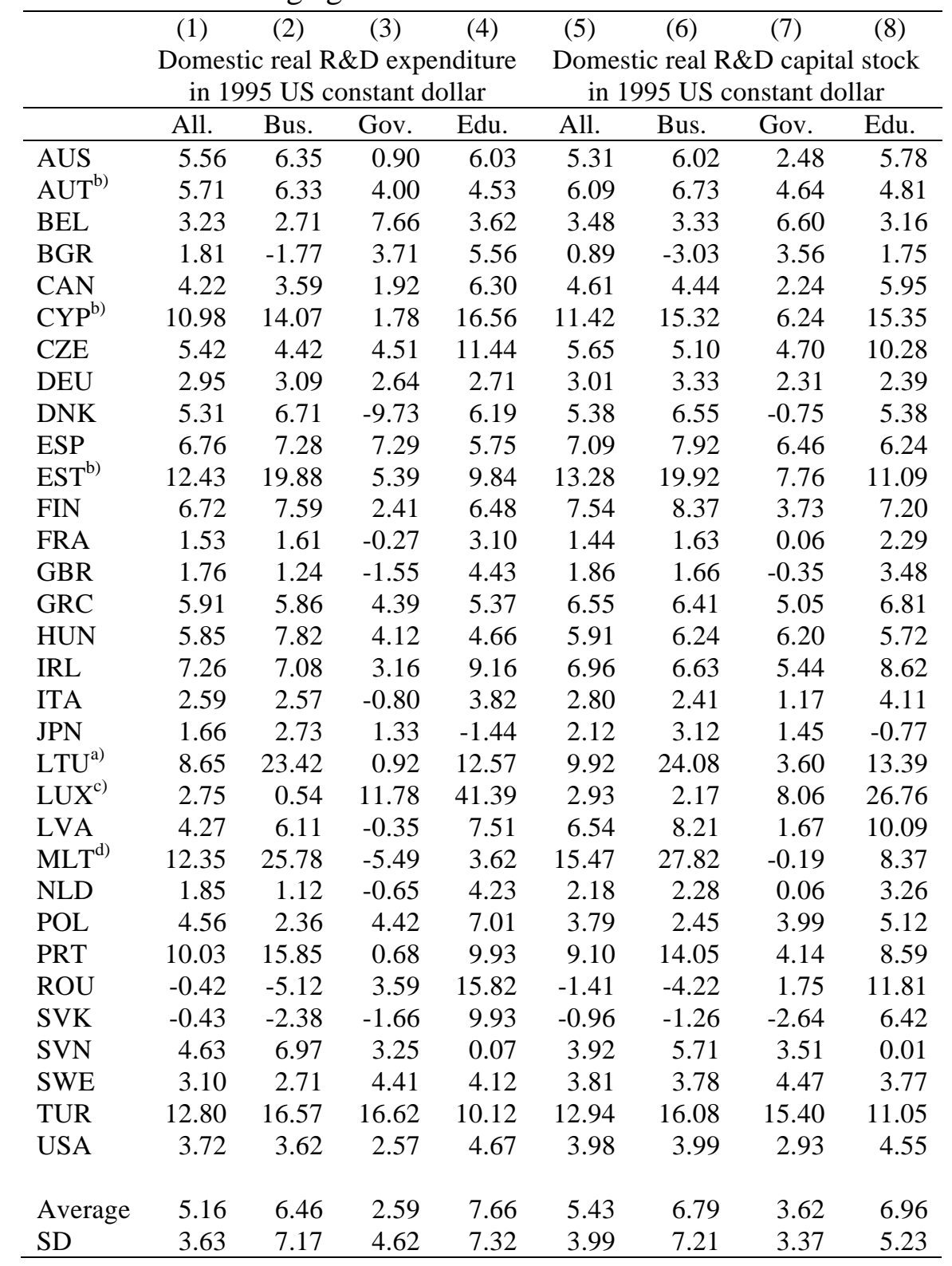

Note: The annual average logarithmic growth rate, i.e., $g=\left(\ln x_{T}-\ln x_{T-t}\right) / t$, in percentage. For countries with superscript a) sample period is 1996-2009, b) 1998-2009, c) 2000-2009 and d) 2002-2009 due to data availability. SD stands for standard deviation. 